\title{
MISALLOCATION, EDUCATION EXPANSION AND WAGE INEQUALITY
}

\author{
Theodore Koutmeridis *
}

\begin{abstract}
This study offers a unified explanation for the perplexing fact that the education premium rises more for low-experienced workers, while the experience premium increases mainly for low-educated labor. The interaction of signaling, employer learning and credit constraints resolves this puzzle. When higher education expands, talented individuals acquire skills and abandon the uneducated pool. This decreases unskilled-inexperienced wages and boosts inequality, highlighting that talent misallocation compresses wage dispersion. This explanation fits US data, indicating that for three decades the rise in the education and the experience premium coincided with falling unskilled-inexperienced wages, while skilled or experienced wages remained relatively flat.
\end{abstract}

The sharp increase in US wage inequality seems to be a point of agreement among social scientists and policy makers. Nevertheless, we still lack a rigorous understanding of its causes and consequences. Some patterns of increasing inequality, such as the rise in the education premium, are well documented in the literature, while other aspects and importantly the growing experience wage premium, are less well reported, if not entirely absent from most of the existing studies. Between the 1970s and the 2000s rising inequality has coincided with the advancement of the American economy that offered more opportunities to historically disadvantaged groups. These opportunities relate to various dimensions of social life, from accessing higher education to starting a business. Even though there is a debate of whether growing wage inequality should be a policy concern, there is a consensus that easier access to higher education is beneficial for social progress. This paper provides an explanation for the puzzling patterns of US wage distribution and establishes that the improved access to higher education played an important role in generating more opportunities but also in boosting wage inequality, by marginalizing further low educated young workers.

During the past forty years the average level of schooling increased sharply in the US, while wage inequality between different education groups has grown too. Most of the existing papers focus on technology to provide an explanation for the increasing college wage premium, despite the rising supply of educated workers. In spite of its importance in understanding the effects of technical change on inequality, this approach fails to explain the evolution of wage inequality within different education-experience groups and the large decline in the real wage for unskilled and inexperienced workers. ${ }^{1}$

Several studies document the rise in the education wage premium but they usually focus

\footnotetext{
* Corresponding author: Theodore Koutmeridis, Department of Economics, Adam Smith Business School, University of Glasgow, 10 The Square, Glasgow G12 8QQ, UK. Email: theodore.koutmeridis@glasgow.ac.uk.

I wish to thank David Autor, Abhijit Banerjee, Roland Benabou, Ken Binmore, Tobias Broer, Arnaud Costinot, Mirko Draca, Henry Farber, Oded Galor, Sayantan Ghosal, William Kerr, Philipp Kircher, Fabian Lange, Victor Lavy, Rocco Macchiavello, Omer Moav, Robin Naylor, Andrew Oswald, Herakles Polemarchakis, Ruth Towse, Gianluca Violante, Fabian Waldinger, Michalis Zaouras, Fabrizio Zilibotti and particularly Sascha O. Becker and Paulo Santos Monteiro for their comments. I also thank participants at NYU Stern, Warwick, Oxford, Glasgow, St Andrews, Edinburgh, Stockholm, Goethe Frankfurt, New Economic School, Barcelona and Alicante, as well as at EEA (Geneva), SOLE (Montréal), IZA@DC (Georgetown), RES (Cambridge), EALE (Paphos) and IZA (Ammersee). Financial support from the British Academy (Rising Star Engagement Award), the Royal Economic Society (Junior Fellowship), the Scottish Economic Society (Sir Alec Cairncross Prize), the European Science Days (Award in Signaling Theory), the Onassis Foundation, Warwick and Glasgow universities is gratefully acknowledged.

${ }^{1}$ Katz and Murphy (1992) offer an early contribution on technology-skill complementarities. Acemoglu (2002), Hornstein et al. (2005) and Acemoglu and Autor (2011) review this literature, while Card and DiNardo (2002) critisize this explanation.
} 
on the average ratio of both experienced and inexperienced workers. ${ }^{2}$ A more cautious examination reveals that the education premium rises sharply for less experienced workers and only moderately for the highly experienced ones (Card and Lemieux, 2001). ${ }^{3}$ Similarly, the experience premium grows mainly for less educated labor (Katz and Murphy, 1992). ${ }^{4}$ Intuitively, it seems that in the absence of experience wage inequality is influenced more by education, while the lack of higher education allows experience to primarily affect wage inequality. A potential explanation for the combination of these facts is that ability is revealed to firms either through formal education signals or with experience as employers observe and informally learn their workers' talents.

The introduction of private employer learning in a model of signaling with credit constraints explains these patterns. My theory suggests that asymmetric information and credit constraints do not allow firms to distinguish the poor but able individuals from the less-able ones, resulting initially in a pooling wage for all uneducated workers. However, with experience firms privately learn their workers' type. Private learning implies that incumbent firms are better informed for the type of their own employees compared to potential competitors.

Privately observable performance allows firms to derive an information rent by sorting their workers better, which leads to different wage paths for uneducated workers, depending on their revealed ability-type. When access to higher education increases, a larger fraction of talented individuals can acquire education and leave the uneducated pool. This implies that the eventual group of uneducated young workers becomes of lower average quality, as most of the rough diamonds have now been plucked out of this group. In response, firms interpret the lack of college education as a clearer indication of low talent and offer lower wages to the remaining unskilled inexperienced workers, which boosts wage inequality.

The main contribution of this microfounded explanation is the revelation of a new unified theory based on the decline of unskilled inexperienced wages that explains the following key US wage inequality facts, especially during 1970-1996: i) the increase in the education premium despite the growing supply of skills; $i$ ) the understudied increase in the experience premium; iii) the large rise in the education premium for inexperienced workers and its moderate expansion for the experienced ones, iii) the puzzling coexistence of rising experience premium for low-educated workers and its flat pattern for the highly educated ones. ${ }^{5}$

An important prediction of the model is that unskilled inexperienced wages decline and this is the common factor that increases both the education premium for low-experienced workers and the experience premium for low-educated workers, which in turn drive most of the rise in the pooled education and experience premium, respectively. Using the Current Population Survey (CPS), I show that US data from 1970 to 1996, the period when wage inequality increased sharply, confirm this prediction. Figure 1 indicates that during this period the rise in the education and the experience premium coincides with a fall in unskilled inexperienced wages (denominator), while skilled or experienced wages (numerator) do not

\footnotetext{
${ }^{2}$ We use the terms education, college and skill premium interchangeably.

${ }^{3}$ Guvenen and Kuruscu (2010) offer an explanation based on human capital investments which is consistent with a larger increase in the education premium for younger and therefore, low-experienced workers.

${ }^{4}$ Guvenen (2007) highlights that not only the wages but also the life-cycle profiles of consumption are different for low and high educated workers, while Primiceri and van Rens (2009) reconcile differences between income and consumption inequality by allowing for predictable changes in permanent income. Kaymak and Poschke (2016) show that increased wage dispersion affects more income and consumption inequality compared to changes in taxation which have a minor impact.

${ }^{5}$ These results can also hold when the purely informational model with signaling and employer learning, extends with returns to education due to human capital and returns to experience due to employee learning.
} 
change much. Notice that for the periods before 1970 and after 1996 both the numerator and the denominator increase similarly, leading only to moderate changes in the wage premia and in US wage inequality. ${ }^{6}$ My approach explains changes in real wages but I compare it to the skill-biased technical change (SBTC) one, which focuses on changes in relative wages. The two models are complementary, as I focus on supply factors, while the SBTC approach emphasizes labor demand. The two theories together seem to provide a better understanding of labor income distribution, compared to each approach alone.

\section{Wage Premia: Numerator vs Denominator, US 1963-2008}
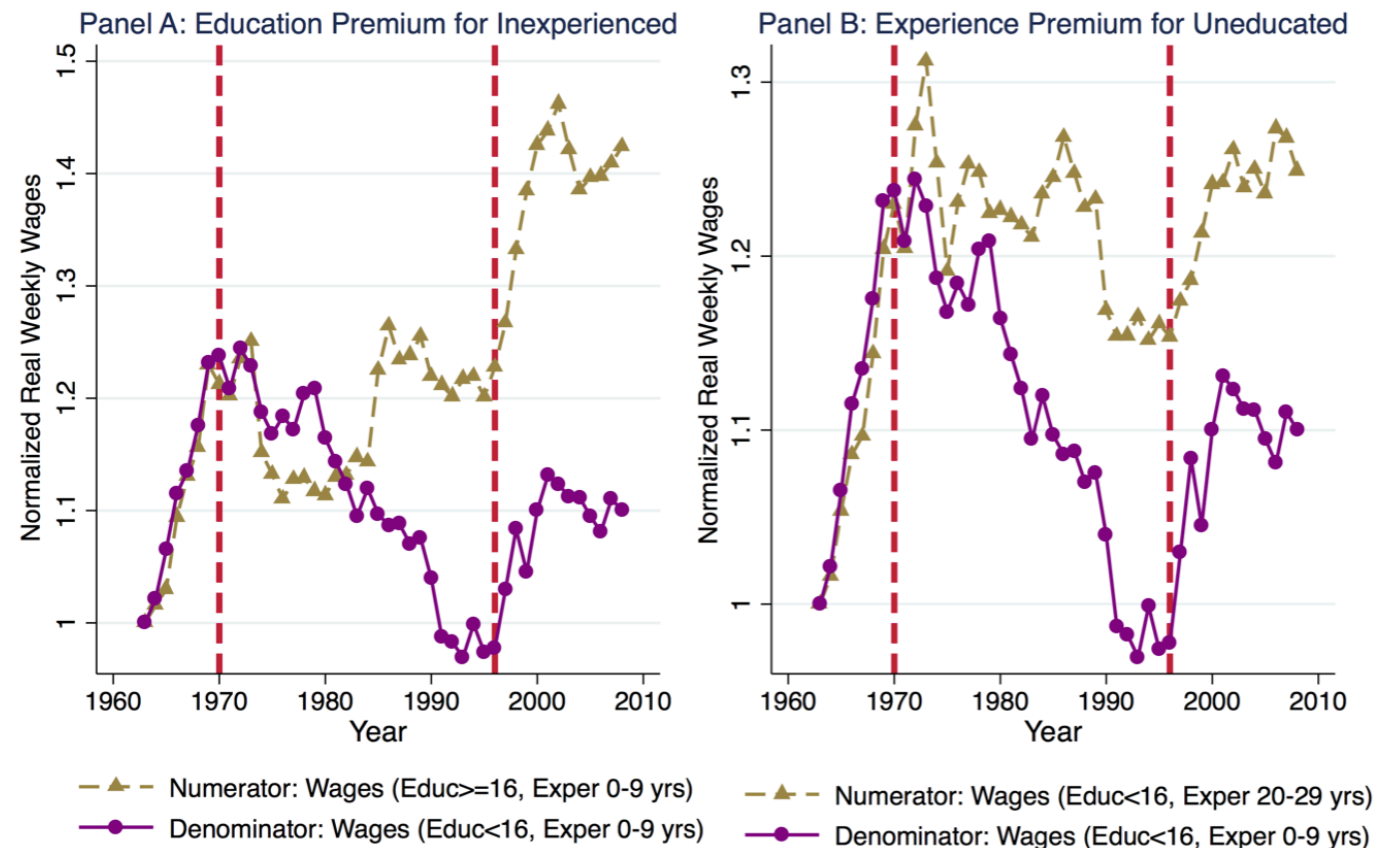

Fig. 1. Numerator vs Denominator. Source. Authors' calculations using the CPS, White Males.

This paper contributes to a microeconomic debate on the signaling and the human capital returns to education. Existing relevant studies relate to three branches of the literature concentrating on signaling, employer learning and credit constraints. In this sense my paper links to earlier models incorporating two of these features. However, none of them builds on a unified framework of all three elements, each of which is crucial in evaluating the effects of education and experience on inequality.

Apart from the "return to education due to human capital", which captures Becker's (1964) idea that education increases productivity, there is also a "return to education due to signaling", which dates back to Spence's (1973) seminal contribution that education also conveys information about worker's ability to uninformed firms. ${ }^{7}$ However, employers can

\footnotetext{
${ }^{6}$ Figure 1 displays normalized real weekly wages. In Section 3, Figure 5 displays the real wages without normalisations and the results are the same. In the same section Table 2 contrasts quantitatively the log wage premia within different educationexperience groups and shows that for the period 1970-1996 the annual time trends in the log education premium regressions for all experience groups, for inexperienced and for experienced workers are $0.0035^{* * *}, 0.0092^{* * *}, 0.0038^{* *}$, respectively. Similarly, the annual trends in the log experience premium regressions for all education groups, for low-educated and for highly educated workers are $0.0020^{* *}, 0.0026^{* * *},-0.0022$ (all regressions adjust for the composition of workers and include a constant, while significance at the 1,5 and 10 percent level is denoted by ${ }^{* * *}, * * *$, , respectively. Our sample includes full-time, full-year white male workers, who are not self-employed, while in the regressions we control for hours worked per week, weeks worked per year and state specific characteristics (all the details appear in Section 3 and in the online Appendix A1).

${ }^{7}$ Bedard (2001) finds that signaling is empirically more plausible than the human capital explanation, while Chevalier et al. (2004) contradict this finding.
} 
also derive information about the type of their workers through labor market experience. In this sense experience can also convey information generating a "return to experience due to employer learning". The non-informational counterpart for experience is the "return to experience due to employee learning" or learning-by-doing. That is why for both education and experience there exists an informational and a non-informational return.

Importantly, employer learning itself can be asymmetric in a dual way. First, current employers learn more about their workers' type compared to potential competitors, which I call "employer learning asymmetric to the firm". Second, a given employer learns more about a particular group of workers, say high school graduates, compared to others, for instance college graduates, which I call "employer learning asymmetric to the worker". Some of these effects have been explored separately empirically or theoretically but no study has examined all these informational aspects of the labor market in a unified framework.

Kahn (2009) strongly favours asymmetric employer learning and Arcidiacono et al. (2010) show that education principally reveals ability, that is why ability is almost perfectly observed for college graduates, while for high school graduates it is gradually revealed with tenure. ${ }^{8}$ That is why employer learning is important only for this group. This is in line with my model of asymmetric employer learning to the firm and the worker, as incumbent firms derive more information for their workers' type compared to competitors and learning matters mainly for less educated employees. ${ }^{9}$

Moreover, this study relates to a policy debate on the importance of credit constraints. Card (2001) highlights the consistently higher IV estimates of education on wages, compared to the standard OLS. He attributes this difference of 20-30 percent to the existence of credit constraints. Carneiro and Heckman (2002) provide an alternative view by showing that at the most an 8 percent of the US population is credit constrained after controlling for long-run constraints related to student ability. ${ }^{10}$

My approach links more to Hendel et al. (2005), which combines credit constraints as in Galor and Zeira (1993) with Spence's (1973) model of job market signaling. ${ }^{11}$ They derive the important result that anything makes education more affordable, such as less severe credit constraints or lower tuition fees, increases the skill premium. ${ }^{12}$ Their influential paper provides a new explanation for the rising education premium but it is inappropriate for the study of the experience premium and the evolution of within group wage inequality.

The main finding in Hendel et al. (2005) that unskilled wages fall and this accounts for the rising education premium, finds weak empirical support. However, once we break down the education premium to different experience groups, I can show that the decline of unskilled inexperienced wages leads to rising wage inequality. Over the period 19701996 real unskilled wages declined only by 6.25 percent, while skilled wages increased

\footnotetext{
${ }^{8}$ See also Bauer and Haisken-DeNew (2001), while Dustmann and Meghir (2005) distinguish general experience from sector and firm-specific tenure and suggest that while the acquisition of skills is key for the wage growth of skilled workers early in their career, unskilled workers benefit primarily from being attached to a particular firm.

${ }^{9}$ Farber and Gibbons (1996) conclude that ability measures, unobserved by employers, are increasingly correlated with wages as experience rises. Altonji (2005) argues that markets might delay to learn that a worker is highly able if her lowskill-level job reveals little about her talent but Schönberg (2007) supports that there is no evidence for asymmetric employer learning, apart from the case of college graduates. See also Jovanovic (1979) for an earlier contribution on employer learning. Heafke et al. (2013) show that new hires respond strongly to changes in labor productivity, revealing a new way in which firms hire workers, especially the younger who have less labor market experience.

${ }^{10}$ Lochner and Monge-Naranjo (2011 and 2012) focus on funding and survey the literature on credit constraints.

${ }^{11}$ Stiglitz (1975) and Krugman (2000) have also shown that better sorting in education rises inequality.

${ }^{12}$ Sun and Yannelis (2016) show that financial deregulation indeed increased the supply of student loans, leading to an increase in college enrollment between the 1970s and the 1990s.
} 
substantially by 10.5 percent and they were mainly responsible for the growth in the skill premium for all experience groups. In contrast, during the same period wages for unskilledinexperienced workers have fallen by 21 percent and this large drop was responsible for the increase in the skill premium for inexperienced workers, as wages for skilled-inexperienced workers remained relatively flat, in fact they increased only slightly by 1.27 percent (see Figure 1 above and Section 3.2). ${ }^{13}$ It is not a coincidence that experience and the inclusion of employer learning in an education signaling model explains the perplexing patterns of wage inequality. Lange (2007), has shown empirically that the signaling value of education depends on employer learning, suggesting that also theoretical studies should combine employer learning and signaling, which is precisely what I do. ${ }^{14}$

This extension with focus on experience not only explains some puzzling empirical facts but also yields some realistic policy implications, while it contributes to an issue that the canonical model of SBTC fails to explain. According to Acemoglu and Autor (2011) "despite its notable successes, the canonical model is largely silent on a number of central empirical developments of the last three decades, including significant declines in real wages of low skill workers, particularly low skill males". This paper explains this key fact and focuses mainly on white males, as different ethnic groups have been influenced by other important societal developments.

This paper also contributes to a macroeocnomic debate related to technology and wage inequality. Katz and Murphy (1992) suggest that in the US the contribution of education and experience on wages has increased since 1970s despite the rising supply of skills, mainly due to technology-skill complementarity. ${ }^{15}$ Krueger et al. (2010) show that the skill premium increases in Anglo-Saxon counties, while it does not change much and it even declines in some continental European countries. However, the significant rise in the experience premium is similar for most countries and consists a fact that has been overlooked by most of the existing studies. ${ }^{16}$ My study fills this gap in the macro-labor literature.

Heathcote et al. (2010) stress that "in the literature, the rise in the experience premium has received much less attention than the skill premium". Card and DiNardo (2002), suggest that the evidence linking growing wage inequality to SBTC is weak, while the emphatic focus on technology has diverted attention away from other interesting developments in the wage structure, such as the rising experience premium, which cannot be easily explained by SBTC. ${ }^{17}$ They conclude that technology might have been responsible for the widening inequality of the 1970s; however, since 1980s other factors might had a stronger influence. ${ }^{18}$ My study shows that the decline in unskilled inexperienced wages offers a

\footnotetext{
${ }^{13}$ Song et al. (2016) show that most of the decline in the wages of low-skill workers occurred in large firms.

${ }^{14}$ Altonji and Pierret (2001), Lange (2007) and Kaymak (2012) show that a high speed of employer learning leads to a limited signaling value, which is 23 to 25 percent of the total value of education.

${ }^{15}$ Berman et al. (1998) and Machin and Van Reenen (1998) provide international evidence supporting SBTC, while Acemoglu (2003) proposes that SBTC was stronger in the US than in Europe.

${ }^{16}$ Murphy and Welch (1992), Juhn et al. (1993), Lemieux (2006a) and Goldin and Katz (2007) also suggest that education and experience explain a large component of wage variation.

${ }^{17}$ See also Baller and van Rens (2013) who contradict the SBTC approach by showing that technological improvements in capital substituted skilled workers more than unskilled workers. This debate extends to the causes of rising residual wage inequality, which according to Violante (2002) relates to SBTC, while Lemieux (2006b) challenges this view, highlighting measurement error problems. Nevertheless, Autor et al. (2008) offer new support to the SBTC approach, reviving this debate on the causes of wage inequality.

${ }^{18}$ They stress the importance of minimum wages on wage inequality (see also Autor et al., 2016). For literature reviews on other causes of inequality, such as trade liberalization, immigration and labor unions, see Card et al. (2004), Card (2009), and Harrison et al. (2011).
} 
new unified explanation for the rise in both the education and the experience premium between 1970 and 1996. Unambiguously, there exist other important theories explaining the evolution of inequality. Yet, this empirically plausible explanation contributes significantly by emphasizing some key aspects which has been ignored by the existing literature.

The surprisingly few existing studies that examine the experience premium are based on: SBTC with on-the-job training (Heckman et al., 1998), general purpose technologies (Aghion et al., 2002), technology-experience complementarity in adoption (Weinberg, 2004), vintage human capital (Hornstein et al., 2005), demographic change (Jeong et al., 2015), and experience-biased technical change (Caselli, 2015). These studies emphasize how technology affects experience, while I focus on the informational component of experience. ${ }^{19}$

The most important theoretical explanations on the college premium, relate to directed technical change (Acemoglu, 1998 and Kiley, 1999) and technological revolutions (Caselli, 1999). ${ }^{20}$ Among the studies focusing on technology, the most relevant to my paper is the influential contribution by Galor and Moav (2000), according to which ability-biased technological transition captures both the increasing supply of skills and the rise in wage inequality between and within different skill groups. A common dimension in the two models is that both mine and theirs predict the decline in unskilled wages. The two distinguishing features, relate to the fact that I also examine the experience premium and I provide an explanation based on market failures, while they mainly focus on education and technology. ${ }^{21}$

Sections 1 and 2 provide the theoretical model and the comparative statics analysis. Section 3 examines whether the theoretical predictions are consistent with data. Section 4 explores the relation of this study to the SBTC approach and show how this explanation fits the data. Section 5 discusses, while the last Section concludes. ${ }^{22}$

\section{A Theoretical Model of Talent Misallocation}

The theoretical model builds on Hendel et al. (2005), which combines Spence's (1973) signaling approach with credit constraints as in Galor and Zeira (1993) to explain how the skill premium increases when higher education becomes more easily accessible. A distinguishing feature of my model is the introduction of private employer learning, which allows us to examine not only the education but also the experience premium and within group wage inequality.

\subsection{Preliminaries}

Agents.- In this economy people live for three periods, time is discrete, and the total population is comprized of heterogeneous agents. In the mass one of total population

\footnotetext{
${ }^{19}$ For the impact of growing labor supply when the baby-boom generation entered the labor market see Dooley and Gottschalk (1984). See also Lagakos et al. (2012) who analyse international data and find that the experience premium is flatter in poor countries.

${ }^{20}$ Importantly, Autor and Dorn (2013) explain that technology has mainly routinized tasks in the middle of the skill distribution, leading to employment and wage polarization. Buera and Kaboski (2012) offer a different explanation and show that the rise of the service economy increased the relative wages of skilled workers.

${ }^{21}$ Gould et al. (2001), show that depreciation of technology raises wage inequality within skill group. Karabarbounis and Neiman (2014) argue that since 1980s advances in information technology not only increased the skill premium but also the capital to labor ratio and show that most of the decline in labor share came from the mining, transport and manufacturing industries that typically employ low-skill young men. Ciccone and Papaioannou (2008) show that higher initial education levels lead to faster growth of human-capital-intensive industries, revealing a channel through which education boosts economic growth.

${ }^{22}$ See online Appendices for data sources, the case of zero-profits and continuum types, respectively.
} 
there are two types of workers, a proportion $\pi$ of high ability workers (good types) and a proportion $1-\pi$ of low ability ones (bad types). Workers have private information about their own type. Each worker produces $q^{j}$, where $j=\{l, h\}$. In particular, the low ability worker produces $q^{l}$ units of output and the high ability one produces $q^{h}$ units $\left(q^{h}>q^{l}\right)$. In addition to differing in ability, workers also vary in their initial wealth endowments. Therefore, there are two sources of heterogeneity stemming from innate ability and initial wealth differences.

The cost of education is dual. There is a direct fixed tuition cost $T$ and an indirect differentiated effort cost depending on agent's type. The effort cost is higher for the low ability worker $k^{l}>k^{h}$. This notion of indirect cost captures Spence's (1973) idea that education is more challenging for less able students. Spence measures the added effort required for low ability students to graduate from college as an argument of the utility function. For simplicity, here this is modeled as a monetary cost. ${ }^{23}$ Without loss of generality, it is also assumed that $k^{h}=0$.

Every period people can either work or go to school, which encapsulates the opportunity cost of education. Although, some find it profitable to acquire education when young or in the second period of their lives, no rational agent prefers to invest in education in the final period of her life, as there is no period to get the return of her investment in schooling. If they acquire education when young, they work as skilled for the second and third period of their lives, for a wage $w_{2}^{s}$ and $w_{3}^{s}$, respectively. If they do not acquire education, they work for the unskilled wage $w_{1}^{u}$ during the first period of their lives but in the second period some of them can cover the cost of education using the unskilled wage they have accumulated in period one, without accessing the costly credit markets. Notice that education is a mere signal, since it does not affect worker's productivity. ${ }^{24}$

Firms.-Companies compete for workers and set wages (Bertrand competition). Firms are interested in productivity, which is unobservable in the first period. That is why they observe workers' actions, they form beliefs and they set the first period wages accordingly. In the second period, firms privately learn the productivity of their employees. We require at least two firms in order for wages to equal the perfectly competitive ones. The production function exhibits constant returns to scale in labor, which is the only input (see Section 5 for diminishing returns and SBTC). In particular, the low ability agent is endowed with productivity $q^{l}$, while the high type is endowed with $q^{h}$, where $q^{h}>q^{l}$. Firms pick a mixture of wages that maximizes their profits.

Timing.-The sequence of events is essential in this three-period model. In particular, during the first period some agents go to college, while others work after signing one-period contracts. At the end of this period they receive the wages agreed and they invest all their wealth in one-period bonds, for an interest rate $r^{l}$. Some borrow at a higher interest rate $r^{b}$ in order to access education. All loans are paid back in the last period of agents lives. ${ }^{25}$

During the second period of their lives firms privately observe workers' productivity.

\footnotetext{
${ }^{23}$ One can think of this cost as paying additional tutors, purchasing extra materials or simply time costs.

${ }^{24}$ This paper examines the signaling approach of wage determination. However, this informational model can be augmented with the human capital one (see Section 4).

${ }^{25}$ For simplicity, loans taken either in period one or two, are reimbursed at the end of period three.
} 
Uneducated workers decide whether to go to school when old or not, using the unskilled wage $w_{1}^{u}$ they have earned. At the end of the second period they receive the payment agreed and they invest their wealth in bonds. In the third period, which is also the final one, employees provide their labor, receive the corresponding wages, repay their loans and consume their lifetime earnings.

Firms privately observe workers' productivity during the first period of employment and in the second period they know to which ability-group their employees belong. However, this is private information for each firm. If workers want to find skilled employment in other firms, they still have to acquire education in the second period of their lives. Furthermore, it is worth mentioning that the return to school investments can be higher compared to the return of bond investments. Thus, agents first examine the possibility of investing in education and then in bonds.

Market Failures.-The functioning of the economy is affected by three market failures: $i$ ) asymmetric information, ii) credit market imperfections and iii) private employer learning. Agents have a private information about their ability type. Individuals of high ability invest in education, try to signal their type to their potential employers and this sorting increases their wage. Education is a costly signal, as in Spence (1973) and the total cost differs depending on agents' type.

The second market failure relates to credit constraints, which are modeled as in Galor and Zeira (1993). There is a lending interest rate $r^{l}$ and a borrowing interest rate $r^{b}$ and it is true that $r^{b}>r^{l}$. The difference between the two rates of interest stems from the possibility of defaulting, which requires the adoption of a costly screening technology by the lenders. In this partial equilibrium small-open-economy framework, $r^{l}$ equals the world interest rate. That is why the relatively less wealthy agents cannot invest in education. This assumption combined with the asymmetries of information render firms incapable of distinguishing the low-type from the credit constrained high-type worker, as in Hendel et al. (2005).

The new element of my model is that employers privately observe workers' performance and after a period of employment the type of each worker is revealed. That is why after a period of employment only the incumbent firm knows the type of its own workers. Competitors still face informational frictions regarding the type of potential new workers.

Together with price taking behavior and constant returns to scale, we also assume that human capital investments are indivisible, which implies that education is a discrete binary choice taking either value 1 or 0 . One can think of this as higher education completed or not.

Lifetime Earnings.-Each agent $i$ maximizes his lifetime earnings $y^{i}$, given his ability type $j$ and initial wealth $b^{i}$. In this economy there are four groups of workers. I calculate lifetime earnings for each group.

Self-Funded Young Students (Group A): The first group is comprized by those who have enough wealth to cover the tuition and the effort cost when young without borrowing. Those with wealth $b^{i} \geq T+k^{j}$ get a lifetime income of:

$$
y^{A}=\left(1+r^{l}\right)^{2}\left(b^{i}-T-k^{j}\right)+\left(1+r^{l}\right) w_{2}^{s}+w_{3}^{s} .
$$

Young Borrowers (Group B): Workers with wealth $b^{i} \in\left[b^{*}, T+k^{j}\right)$ can access profitably the 
credit markets. However, since they cannot cover the total cost of education, they seek for external funding, they borrow and their lifetime income is:

$$
y^{B}=\left(1+r^{b}\right)^{2}\left(b^{i}-T-k^{j}\right)+\left(1+r^{l}\right) w_{2}^{s}+w_{3}^{s} .
$$

In the second period, workers who have worked as unskilled know that their employment firms have observed their productivity. So, they can bargain with their employment firms, using the possibility of acquiring education when old and working for other firms. Notice that even workers with zero initial wealth can cover the tuition cost using their first-period labor income, provided that $w_{1}^{u}>T$. The crucial point is whether they are talented enough to cover the effort cost $k^{j}$.

Self-funded Old Students (Group C): Workers with $b^{i} \in\left[T+k^{j}-\left(1+r^{l}\right) w_{1}^{u}, b^{*}\right)$ can acquire education using their own funds after a period of employment and get:

$$
y^{C}=\left(1+r^{l}\right)^{2}\left(w_{1}^{u}+b^{i}\right)-\left(1+r^{l}\right)\left(T+k^{j}\right)+w_{3}^{s} .
$$

There could also be old borrowers but as you will see later on we exclude this case.

Uneducated (Group D): Agents with initial wealth $b^{i}<T+k^{j}-\left(1+r^{l}\right) w_{1}^{u}$ remain uneducated. These agents get a lifetime income of:

$$
y^{D}=\left(1+r^{l}\right)^{2}\left(w_{1}^{u}+b^{i}\right)+\left(1+r^{l}\right) w_{2}^{u, j}+w_{3}^{u, j} .
$$

Assumptions.- - I propose the following assumptions that influence agent's actions. At this stage these assumptions depend also on endogenous variables but once I solve the game (under these assumptions), I will be able to substitute out the endogenous variables and check whether the equilibrium that I guessed can be verified. In particular:

Assumption 1 (AS1): The effort cost for the low type is sufficiently high.

$$
k^{l}>\frac{\left(1+r^{l}\right)\left(w_{2}^{\varsigma}-w_{2}^{u, l}\right)+w_{3}^{s}-w_{3}^{u, l}-\left(1+r^{l}\right)^{2}\left(w_{1}^{u}+T\right)}{\left(1+r^{l}\right)^{2}}
$$

The intuition is simple: for low types the effort cost $k^{l}$ is high enough that no low type (not even the richest) finds it profitable to invest in education. Assumption 1 comes from the following comparison of lifetime earnings: $y^{D}>y^{A}$.

Assumption 2 (AS2): Even the lowest possible unskilled wage can cover the tuition cost.

$$
T \leq\left(1+r^{l}\right) q^{l}
$$

All constrained high types can go to school when old after working as unskilled in period one, since even the lowest unskilled wage $\left(w_{1}^{u}(\mathrm{~min})=q^{l}\right)$ covers the tuition, which is the only cost for high types (their effort cost is zero: $k^{h}=0$ ). No agent borrows when old.

Assumption 3 (AS3): Credit constraints make it profitable only for some high types to borrow and acquire higher education when they are young.

$$
b^{i} \geq \frac{\left(1+r^{b}\right)^{2} T+\left(1+r^{l}\right) w_{1}^{u}-\left(1+r^{l}\right)\left(w_{2}^{s}+T\right)}{\left(1+r^{b}\right)^{2}-\left(1+r^{l}\right)^{2}} \equiv b^{*}
$$


The above inequality is an incentive compatibility constraint, stating that only some relatively wealthy agents find it profitable to borrow and go to school when young. This relationship comes from the following comparison of lifetime earnings $y^{B} \geq y^{C}$, which implies that at least the richest high types with wealth $b^{i} \geq b^{*}$ prefer to go to school when young rather than when old. Notice that this assumption $y^{B} \geq y^{C}$, also covers the case $y^{A} \geq y^{C}$, which means that high types prefer to go early to school rather than late. This is true since credit constraints imply that when you are young, it is always better to be self-funded rather than borrow $y^{A}>y^{B}$.

Assumption 4 (AS4): High types prefer to separate themselves from the pool of uneducated workers even in the second period of their lives, when they are old.

$$
T<\frac{w_{3}^{s}-w_{3}^{u, P}+\left(1+r^{l}\right) w_{2}^{u, P}}{1+r^{l}}
$$

High types who do not go to school young (those with initial wealth $b^{i}<b^{*}$ ), prefer to separate themselves from the pool of uneducated workers, by going to school when old. Assumption 4 comes from $y^{C}>y_{\text {pooling }}^{D}$. Where $y_{\text {pooling }}^{D}$ is:

$$
y_{\text {pooling }}^{D}=\left(1+r^{l}\right)^{2}\left(w_{1}^{u}+b^{i}\right)+\left(1+r^{l}\right) w_{2}^{u, P}+w_{3}^{u, P} \text {, where } w_{1}^{u} \equiv w_{2}^{u, P} \equiv w_{3}^{u, P} .
$$

Discussion of the Assumptions.-What do these assumptions imply for firm's beliefs? Assumption 1 implies that all educated workers are high types. So, firms know that a signal of higher education can be sent only by high types. This, in turn, implies that the skilled wage equals the productivity of the high type: $w_{2}^{s}=w_{3}^{s}=q^{h}$. Assumption 4 implies that those who do not go to school even in the second period are low types. Thus, the unskilled wages in the second and third period equal the productivity of the low type $w_{2}^{u}=w_{3}^{u}=q^{l}$. This is why the only wage that we have to determine is $w_{1}^{u}$.

Unambiguously there are off-the-equilibrium path beliefs, which I eliminate as unreasonable using the intuitive criterion by Cho and Kreps (1987). In particular, firm's belief that low types acquire education is eliminated, since assumption 1 guarantees that all low types are better off without education due to the high effort cost. Accordingly, the belief that in the second period uneducated high types try to work for other firms for a higher wage can be eliminated too. The logic is that before trying to work for outside firms, high types consider the following two reactions in a forward-looking sense: first, in the absence of education other firms still cannot separate low from high types (private employer learning); second, if uneducated high types try to find a job to other firms for a higher wage, then all low types have an incentive to mimic them, generating a pooling wage for all the uneducated workers $w_{2}^{u, P}=w_{3}^{u, P}=w_{1}^{u}$. However, assumption 4 states that high types prefer to separate themselves from low types by going to school when old rather than pooling with all uneducated workers. By assumption 2 we know that this is feasible as the tuition cost is sufficiently low.

\subsection{Equilibrium}

I employ the following equilibrium concept.

DEFINITION 1: A Perfect Bayesian signaling equilibrium is defined as:

1) choices of education in the first and second period, based on ability and initial wealth: $A_{1}^{*}\left(q^{j}, b^{i}\right) \in$ $\{$ school, not $\}, A_{2}^{*}\left(q^{j}, b^{i}\right) \in\{$ school, not $\}$; 
2) beliefs by firms about worker type in the first period of employment given their education level $B_{1}\left(j \mid A_{1}\right), \forall A_{1}\{$ school, not $\}$ and $B_{2}\left(j \mid A_{2}\right), \forall A_{2}\{$ school, not $\}$;

3) and equilibrium wages: $w_{1}^{u}, w_{2}^{u, h}, w_{2}^{u, l}, w_{2}^{s}, w_{3}^{u, h}, w_{3}^{u, l}$ and $w_{3}^{s}$.

Such that: (i) workers maximize their lifetime earnings, (ii) firms maximize their profits and (iii) labor markets clear.

We have determined all wages apart from the unskilled wage in the first period $w_{1}^{u}$, which we have to derive to find an equilibrium.

Supply of Unskilled Inexperienced Labor.-The supply for unskilled inexperienced labor can be denoted as follows:

$$
P(u \mid h)=P\left(b^{i}<b^{*}\right) .
$$

Where $P(\cdot)$ represents the cumulative density function of the initial wealth distribution for high ability workers.

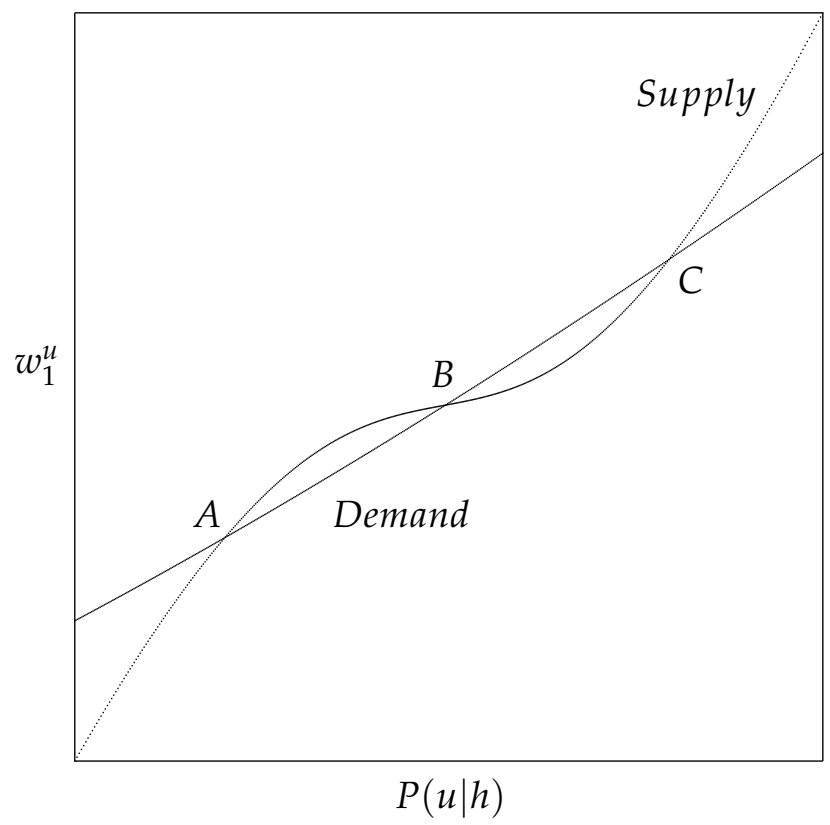

Fig. 2. Unskilled Inexperienced Labor

Figure 2 shows how the parameters of the model affect the supply curve. $P(u \mid h)$ represents the probability that a high ability worker is unskilled. The higher $b^{*}$ is, the greater is the number of high ability agents who do not get an education: $b^{*} \uparrow \Rightarrow P(u \mid h) \uparrow$. The supply curve is upward sloping, as a rise in unskilled wages in period one raises the wealth cutoff $b^{*}$ by reducing the payoff from education, which raises $P(u \mid h)$ (see equation (7) above).

In particular, we are interested in the implications of changes in college education. In our model there are two parameters which affect access to higher education, the level of tuition cost and the degree of credit constraints. An increase in the tuition cost $T$ increases $b^{*}$ by driving down the return to education. So, for any given unskilled wage, a larger fraction of high type workers do not get an education, shifting the supply curve to the right. 
Importantly, when access to higher education contracts due to more severe credit market imperfections, which algebraically translates to an increase in the difference between the borrowing and the lending rates of interest $r^{b}-r^{l}$, shifts the supply curve to the right but also reduces its slope (the supply curve rotates clockwise). Notice that $r^{l}$ is constant and equal to the exogenous world interest rate, that is why an increase of $r^{b}$ makes credit frictions more severe. The inverse results hold when access to college expands by less sever credit constraints. In Section 2 we are going to examine formally how college expansion affects the education and the experience premium within different groups of experience and education, respectively.

Changes in the borrowing rate $r^{b}$ for a given world interest rate $r^{l}$, affect the degree of financial development, which is important for the comparative statics analysis. To see why, re-write $b^{*}$ from equation (7) as:

$$
b^{*}=\frac{\left(1+r^{b}\right)^{2} T+\left(1+r^{l}\right) w_{1}^{u}-\left(1+r^{l}\right)\left(w_{2}^{s}+T\right)}{\left(1+r^{b}\right)^{2}-\left(1+r^{l}\right)^{2}}
$$

From the above equation it is clear that for a given world interest rate $r^{l}$ an increase in the borrowing interest rate $r^{b}$ leads to a higher $b^{*}$ and thus to a higher supply of unskilled labor. Furthermore, a larger $r^{b}$ increases the slope of the supply curve. Intuitively, more severe credit constraints imply that workers are more sensitive to changes in the returns to education. Overall, holding other variables constant it is true that:

(i) Changes on the Supply curve: $P\left(b^{i}<b^{*}\right)\left(w_{1}^{u}(+) ; T ; r^{b}\right)$. A rise (fall) in $w_{1}^{u}$, raises (drops) the probability that a high type is uneducated $P(u \mid h)$.

(ii) Shifts of the Supply curve: $P\left(b^{i}<b^{*}\right)\left(w_{1}^{u} ; T(+) ; r^{b}\right)$. A rise (fall) in the tuition cost $T$, shifts the supply curve outwards (inwards).

(iii) Changes in the Slope of the Supply curve: $P\left(b^{i}<b^{*}\right)\left(w_{1}^{u} ; T ; r^{b}(+)\right)$. A rise (fall) in the borrowing interest rate $r^{b}$ both shifts the supply curve outwards (inwards) and raises (drops) the slope of the supply curve.

Demand for Unskilled Inexperienced Labor.-The demand curve is in fact firm's willingness to pay for a given mix of high and low ability workers. Since firms compete over workers, their willingness to pay a wage equals the expected productivity. Constant returns to scale guarantee that wages do not depend on the quantity of unskilled workers (we relax this assumption in Section 4). Equation (11) below, determines the unskilled wage.

$$
w_{1}^{u}=q^{l}\left(\frac{1-\pi}{1-\pi+\pi P(u \mid h)}\right)+q^{h}\left(\frac{\pi P(u \mid h)}{1-\pi+\pi P(u \mid h)}\right) .
$$

Solving (11) for $P(u \mid h)$ gives the following demand function:

$$
P(u \mid h)=\frac{1-\pi}{\pi}\left(\frac{w_{1}^{u}-q^{l}}{q^{h}-w_{1}^{u}}\right) .
$$

A key feature of the model is that the demand curve for unskilled workers is upward sloping. Intuitively, as fewer workers get an education, firms realize that the average uneducated 
worker is more likely to be of high ability and thus, firms are willing to pay them more.

Equilibrium Unskilled-Inexperienced Wage.-An equilibrium occurs when the percentage of high ability workers who cannot get an education at an unskilled wage $w_{1}^{u}$ is equal to the percentage of high ability workers that a firm wants to be in the unskilled pool of workers in order to break even by offering wage $w_{1}^{u}$. I use equation $f(\cdot)$ to formalize my argument:

$$
f:\left[q^{l}, q^{P}\right] \rightarrow\left[q^{l}, q^{P}\right]: f\left(w_{1}^{u}\right)=\frac{(1-\pi) q^{l}+\pi q^{h} P\left(b^{i}<b^{*}\left(w_{1}^{u} ; T, r^{b}\right)\right)}{1-\pi+\pi P\left(b^{i}<b^{*}\left(w_{1}^{u} ; T, r^{b}\right)\right)} .
$$

An equilibrium occurs when $f\left(w_{1}^{u}\right)=w_{1}^{u}$. For locally tâtonnement stable equilibria, prices evolve according to $\partial w_{1}^{u} / \partial t=f\left(w_{1}^{u}\right)-w_{1}^{u}$. An equilibrium is locally tâtonnement stable if, whenever the initial price vector is sufficiently close to it, the dynamic trajectory causes relative prices to converge the equilibrium price. The condition of tâtonnement stability is equivalent to the requirement that the slope of the supply curve must exceed the slope of the demand curve. The following proposition summarizes existence and stability.

PROPOSITION 1 (Existence, Stability): Let $P(\cdot)$ be a continuously differentiable function. Then, there exists at least one stable equilibrium.

Proof. I prove proposition 1 in two steps: first I prove existence and then stability. For existence, I apply Brouwer's Fixed Point Theorem, for continuous functions from a nonempty, convex, compact set to itself. Function $f(\cdot)$ is indeed continuous, since $P(\cdot)$ is continuous. The function maps from the set $\left[q^{l}, q^{P}\right]$ to $\left[q^{l}, q^{P}\right]$ and the set is convex and compact, since the unskilled wage $w_{1}^{u}$ can take any value within this set. Thus, from Brouwer's Fixed Point Theorem an equilibrium exists.

Now I prove stability. For locally tâtonnement stable equilibria, prices evolve according to $\partial w_{1}^{u} / \partial t=f\left(w_{1}^{u}\right)-w_{1}^{u}$. If I set the derivative of function $f(\cdot)$ with respect to $w_{1}^{u}$ larger than zero, I find that $q^{h}>q^{l}$, which is always true and means that $f(\cdot)$ is increasing in $w_{1}^{u}$. This implies that when we are in an equilibrium, an increase in the wage must lead to $f\left(w_{1}^{u}\right)-w_{1}^{u}<0$. Now let us take the maximum possible value for $w_{1}^{u}$, which is $q^{P}=q^{l}(1-\pi)+q^{h} \pi$ and occurs when $P(u \mid h)=1$. Taking $f\left(w_{1}^{u}\right)-w_{1}^{u}<0$ for this wage, leads to $q^{h}>q^{l}$, which is always true. Accordingly, a decrease from the equilibrium wage leads to $f\left(w_{1}^{u}\right)-w_{1}^{u}>0$. If instead we take the minimum possible value for $w_{1}^{u}$, which is $q^{l}$ and occurs when $P(u \mid h)=0$, again we conclude that $q^{h}>q^{l}$, which is always true. Since, for the lowest price $w_{1}^{u}=q^{l}$ we have $f\left(w_{1}^{u}\right)-w_{1}^{u}>0$ and for the highest price $w_{1}^{u}=q^{P}$ we have $f\left(w_{1}^{u}\right)-w_{1}^{u}<0$, for a value of $w_{1}^{u}$ in the set $\left(q^{l}, q^{P}\right)$ we must have $f\left(w_{1}^{u}\right)-w_{1}^{u}=0$, which means that there generically exists at least one locally tâtonnement stable equilibrium. Notice that the result holds generically, since we cannot exclude the possibility that the function $f(\cdot)$ is tangent to the diagonal.

If the slope of the supply curve exceeds the slope of the demand curve and under the initial condition for $P(u \mid h)=0$ of excess demand and the terminal condition for $P(u \mid h)=1$ of excess supply, there exists at least one tâtonnement stable equilibrium. Generally, an equilibrium exists when the fraction of high ability workers who cannot get an education coincides with the mass of high-ability uneducated population that firms wish to employ in order unskilled wages to maximize their profits. 
In Figure 2, where the horizontal axis measures the probability that the high type is uneducated $P(u \mid h)$ and the vertical counts the unskilled wage in the first period $w_{1}^{u}$, only $A$ and $C$ are stable equilibria, while $B$ is unstable. Stability implies that the supply curve has a higher slope than the demand curve. Notice that both of them are upward sloping. Now consider a wage $\overline{w_{1}^{u}}$ above the equilibrium level. At this level we have excess demand. ${ }^{26}$ This wage will decline in order to reach the equilibrium level, since for this wage $\overline{w_{1}^{u}}$, we have excess demand for uneducated high types $P(u \mid h)^{D}>P(u \mid h)^{S}$ (recall that demand is the firm's willingness to pay). This means that firms are willing to pay this wage only when the probability that the high type is uneducated is $P(u \mid h)^{D}$. However, the supply of uneducated high-type workers is $P(u \mid h)^{S}$, which is lower than $P(u \mid h)^{D}$. That is why firms set wages at a lower level compared to $\overline{w_{1}^{u}}$. This happens until we reach the locally stable equilibrium. In the same spirit when wages are lower compared to the equilibrium level, we have excess supply of uneducated high types and wages increase until they reach the equilibrium level.

Verify the Solution.-Assumptions (1-4) depend on endogenous variables too but I can now substitute them out, since I have solved for them and these assumptions become:

$$
\text { Assumption 1: } \quad k^{l}>\frac{r^{l}\left(q^{h}-q^{l}\right)-\left(1+r^{l}\right)^{2}\left(w_{1}^{u *}+T\right)}{\left(1+r^{l}\right)^{2}}
$$

$$
\text { Assumption 2: } \quad T \leq\left(1+r^{l}\right) q^{l}
$$

$$
\text { Assumption 3: } \quad b^{*}=\frac{\left(1+r^{b}\right)^{2} T+\left(1+r^{l}\right) w_{1}^{u *}-\left(1+r^{l}\right)\left(q^{h}+T\right)}{\left(1+r^{b}\right)^{2}-\left(1+r^{l}\right)^{2}}
$$

$$
\text { Assumption 4: } \quad T<\frac{q^{h}+r^{l} w_{1}^{u *}}{1+r^{l}}
$$

Notice that all the assumptions above depend on parameters only, since I have proved that an equilibrium wage $w_{1}^{u}$ exists and takes values from $q^{l}$ to $q^{P}$.

Bargaining.-Our analysis so far implies that high ability agents with adequate wealth to acquire education when young, $b^{i} \geq b^{*}$, work for the skilled wage during the second and the third period of their lives $w^{s}=q^{h}$. Similarly, low ability agents never invest in education and work as unskilled for the rest of their lives. However, the determination of the employment path of high ability agents with wealth $b^{i}<b^{*}$ is not so simple. In particular, the discussion so far excludes the possibility of bargaining between firms and workers. Nevertheless, after firms having privately observed the productivity of their workers, there can be mutually beneficial bargaining between firms and workers.

\footnotetext{
${ }^{26}$ Generally, when the demand curve is downward sloping and the supply is upward sloping, for higher prices compared to the equilibrium prices we have excess supply. However, in this graph the demand curve is upward sloping, that is why we have excess demand. Thus in our case (of upward-sloping demand curve), in the condition for local tâtonnement stability $\partial w_{1}^{u} / \partial t=f\left(w_{1}^{u}\right)-w_{1}^{u}$, the function $g(w)=f\left(w_{1}^{u}\right)-w_{1}^{u}$ represents the excess supply function and not the excess demand function, which is generally the case (when the demand curve is downward sloping and the supply curve is upward sloping).
} 
Firms know that high types with $b^{i}<b^{*}$, produce $q^{h}$. However, during the first period they offer them $w_{1}^{u}$, as workers cannot afford signaling their type. During the second period, worker type is revealed to their firms. When old, these workers can bargain for a higher wage and threaten firms that if they do not pay them the high wage that they deserve, they will work for another firm. Their employers argue that other firms do not know their type. That is why in the absence of a college degree they cannot receive the skilled wage. Instead, they get $w_{2}^{u, P}$ and $w_{2}^{u, P}$ for the remaining two periods. Workers reply that they can acquire education to signal their type to other firms and get the skilled wage. By assumption 2 firms know that this threat is credible for all credit constrained high types, who are uneducated in period 1. Consequently, firms agree to offer bargainers the wage $w_{2}^{u, h}=w_{3}^{u, h}=\left[q^{h}-\left(1+r^{l}\right) T\right] /\left(2+r^{l}\right)$ which makes them indifferent between staying attached to the same firm and going to school when old in order to work as skilled for other firms, during the third period. By assumption 4 high types find it profitable to separate themselves from the unskilled pool, even when old. Additionally, under a cost for switching jobs, workers are better off by accepting their employment firm's offer. Similarly, if there is a cost for unsuccessful bargaining, low types will never choose to bargain. Notice that mutually beneficial bargaining implies that nobody invests in education in the second period.

Bargaining generates a return to experience not as a result of a standard learning-by-doing process but as an informational benefit of employer learning, due to the combination of credit constraints and asymmetric information. Successful bargainers receive the wage they would have obtained if they had invested in college when old and thus if they had worked as skilled in the third period. That is why they get $w_{2}^{u, h}=w_{3}^{u, h}=\left[q^{h}-\left(1+r^{l}\right) T\right] /\left(2+r^{l}\right)$ for the second and third period of their lives.

LEMMA 1: In the model described above there is a return to experience due to employer learning. This return is generated as a result of individual bargaining and it is positive for high types and negative for the low types.

High ability workers bargain based on the possibility of acquiring education and finding employment in other firms. This bargaining is successful for all high types, since all of them have enough wealth to cover the cost of education in the second period.

An interesting question is whether employers can offer a higher wage than $w_{2}^{u, h}$ to attract more uneducated high types. The answer is negative, since firms that try to employ workers from competitors face asymmetries of information even during the second period, as they still cannot distinguish the high from the low types. Additionally, when low types observe that credit constrained high types seek for employment, they always have an incentive to mimic them. However, from assumption 4, high types always find it profitable to bargain and separate themselves from pooling with the low types. Furthermore, employers always wish to keep the constrained high types in the firm, since they derive a profit by paying them less than their marginal productivity. That is why an uneducated agent who seeks for employment when old is perceived as a low type and thus gets the lowest possible wage $w_{2}^{u, l}=w_{3}^{u, l}=q^{l}$. Under the time-cost for switching jobs, low types also stay to their employment firm. Importantly, the proposition below states that in this setting firms derive an informational rent.

PROPOSITION 2: Firms derive an information rent as a result of better sorting. The corresponding 
surplus for firms is generated due to the combination of education signaling, credit constraints and privately observable productivity after the first period of employment (private employer learning).

Proof. Firms have zero profits in the first period and positive profits in the remaining two periods. If firm's profit in the second period is $\pi_{2}$ and if $N^{B}$ is the number credit constrained high types (bargainers) employed by each firm, then it is true that $\pi_{2}=N^{B}\left(q^{h}-w_{2}^{u, h}\right)$. This is always positive since $w_{2}^{u, h}=\left[q^{h}-\left(1+r^{l}\right) T\right] /\left(2+r^{l}\right)$. This implies that $\pi_{2}=$ $N^{B}\left(q^{h}+T\right)\left(1+r^{l}\right) /\left(2+r^{l}\right)$, which is positive too. Notice also that $w_{2}^{u, h}=w_{3}^{u, h}$ and therefore $\pi_{2}=\pi_{3}$. That is why during period two and three profits are positive for all firms.

Intuitively, firms initially employ workers without deriving profits. However, as they learn the type of their employees, they can sort them and obtain a surplus. ${ }^{27}$ Firms derive a profit by offering the bargaining agents a lower wage compared to their productivity, since they subtract the tuition cost from the offered wage and they split it in the remaining two periods of employment. Bargaining is mutually beneficial for both firms and bargainers.

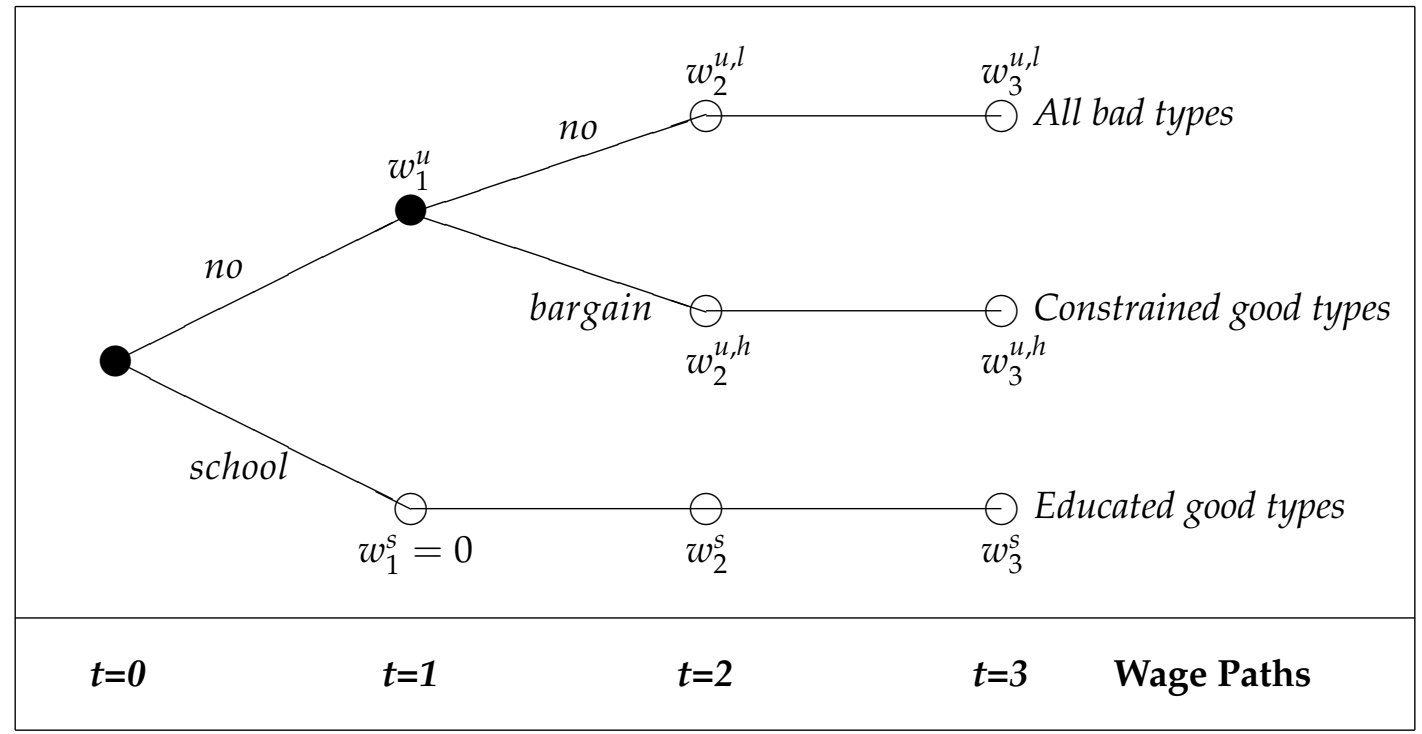

Fig. 3. Equilibrium Tree

The functioning of the Economy.-So far, I have presented the basic features of the model and now I can review the functioning of this economy using Figure 3. The black nodes denote that a decision is taken by the agent, while in the transparent nodes there is no option by the agent and the employment path is predetermined by previous choices. On the branches I display the choices and on the nodes the wages. The figure also displays the wage path for each agent. This graph facilitates in understanding the functioning of the economy.

\section{Comparative Statics When Higher Education Becomes More Easily Accessible}

This Section examines wage inequality when higher education becomes more easily accessible. In a stable equilibrium, anything that expands higher education by making it easier

\footnotetext{
${ }^{27}$ This happens because firms maximize profits at each period. However, even if they could transfer profits from later periods to the first one (or if they could borrow) to attract the credit constrained high types, they would have zero profit across the three periods, without this affecting any of the results (see online Appendix A2). In a dynamic setting zero profits would be more realistic as individuals would live for three periods and firms perpetually, therefore they would be able to transfer profits from one period to another. See Koutmeridis (2013a) and Koutmeridis (2013b) for an extension of the 3-period static model to a dynamic 3-period overlapping generations (OLG) models, in the spirit of Allais (1947), Samuelson (1958) and Diamond (1965).
} 
or more attractive for people to go to college, raises the education premium. The intuition is simple. Lowering the borrowing rate or tuition fees shifts the supply curve for unskilled inexperienced labor to the left. With a normal downward-sloping demand curve, such a shift leads to a rise in wages since demand would exceed supply. However, in our model the demand curve is upward-sloping, thus unskilled inexperienced wages decrease and the education premium rises. When the borrowing interest rate drops, education expands, fewer high ability workers remain uneducated and by (10) we can see that $b^{*}$ falls, generating a decrease in the initial wage of unskilled inexperienced workers, which in turn leads to an increase in the education premium. However, the education premium increases also for experienced workers as fewer high types are uneducated even in the second period. This logic is summarized below:

PROPOSITION 3: In any stable equilibrium, when higher education expands due to the relaxation of credit constraints, the education premium increases for both experienced and inexperienced workers.

Proof. Recall that an expansion of higher education due to a relaxation of credit constraints triggers the following effects: $b^{*} \downarrow \Rightarrow P(u \mid h) \downarrow \Rightarrow w_{1}^{u} \downarrow$. Notice that there are two education premia. The first one is the education premium for inexperienced workers, which is denoted as $w_{2}^{s} / w_{1}^{u}$. From (10) we can see that in a stable equilibrium a fall in $r^{b}$ decreases both $b^{*}$ and $w_{1}^{u}$. Therefore, the first education premium $w_{2}^{s} / w_{1}^{u}=q^{h} / w_{1}^{u}$ increases. The second education premium is for experienced workers and it is denoted as $w_{3}^{s} / \underline{w}_{2}^{u}$. Notice that $\underline{w}_{2}^{u}$ stands for the average wage of the uneducated worker, regardless of whether he bargains or not (put it differently, regardless of being a high or a low type). This wage depends on the number of low types getting the wage $w_{2}^{u, l}=q^{l}$ and the number of credit constrained high types getting $w_{2}^{u, h}$, which is higher than $q^{l}$. Observe also that a fall in $r^{b}$ decreases the number of bargainers who get the higher wage $w_{2}^{u, h}$ and therefore it decreases the average wage of the uneducated worker in period $2 \underline{w}_{2}^{u}$. Given that $w_{3}^{s}$ is constant an equal to $q^{h}$, the second education premium increases too. Thus, the education premium raises for both inexperienced and experienced workers as education expands by less severe credit frictions (see Appendix A3 for a continuum of ability types).

Anything that makes higher education more easily accessible, such as less severe credit constraints, decreases unskilled inexperienced wages, which in turn increases the experience premium too. Notice that the rise in the experience premium is generated only for the group of less educated workers and not for the highly-educated ones. Formally the proposition below holds:

PROPOSITION 4: In any stable equilibrium, when higher education expands due to the relaxation of credit constraints, the experience premium increases only for less educated workers. For highlyeducated workers the experienced premium remains unchanged.

Proof. There are three experience premia, one for the highly educated workers and two for the low educated workers. For the highly educated workers it is $w_{3}^{s} / w_{2}^{s}=q^{h} / q^{h}=1$. For the low educated workers one experience premium is computed by comparing their wages of the first and second period $w_{2}^{u} / w_{1}^{u}$ and the other one by comparing the wages of the second and third period $w_{3}^{u} / w_{2}^{u}=1$. Notice that the only experience premium which is

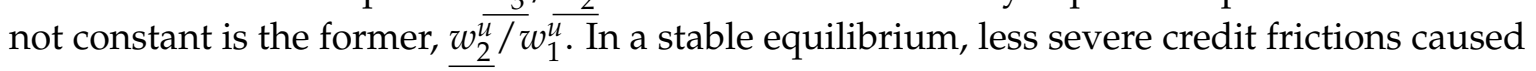
by a decline in $r^{b}$ decrease $\overline{b^{*}}$ and $w_{1}^{u}$. However, the lower cost of borrowing decrease $\underline{w_{2}^{u}}$ as 
well, since fewer high types are credit constrained and fewer agents in the uneducated pool get the higher wage $w_{2}^{u, h}$. This means that both the numerator and the denominator decrease, leaving the overall effect uncertain. Below we compare the experience premium before the expansion of higher education due to the relaxation of credit frictions and the experience premium after it. Proposition 4 will hold if ExpPremium Eefore $<$ ExpPremium $_{\text {after }}$. I suppose that this inequality does not hold and I try to derive a contradiction.

$$
\begin{aligned}
& \text { ExpPremium }_{\text {before }} \geq \text { ExpPremium }_{\text {after }} \\
& \frac{w_{2}^{u}}{\bar{w}_{1}^{u}} \text { before } \geq \frac{w_{2}^{u}}{w_{1}^{u}} \text { after } \\
& \frac{\overline{N_{2}^{h}} w_{2}^{u, h}+N_{2}^{l} q^{l} /\left[\overline{N_{2}^{h}}+N_{2}^{l}\right]}{\overline{N_{1}^{h}} q^{h}+N_{1}^{l} q^{l} /\left[\overline{N_{1}^{h}}+N_{1}^{l}\right]} \geq \frac{N_{2}^{h} w_{2}^{u, h}+N_{2}^{l} q^{l} /\left[N_{2}^{h}+N_{2} l\right]}{\underline{N_{1}^{h} q^{h}+N_{1}^{l} q^{l} /\left[N_{1}^{h}+N_{1}^{l}\right]}}
\end{aligned}
$$

Where $N$ denotes the number of agents, the subscript denote the time-period and the superscript the type of the group. Observe that when credit frictions are more severe there is a larger fraction of high types in the uneducated pool, which I denote with upper-bar $\overline{N_{1}^{h}}$. Accordingly, after the relaxation of credit constraints there are fewer, which I denote with lower-bar $N_{1}^{h}$. I use a similar notation with bars for period two as well. Notice that: $\underline{N_{1}^{h}}=\underline{N_{2}^{h}}$, also $\overline{N_{1}^{h}}=\overline{N_{2}^{h}}$ and $N_{1}^{l}=N_{2}^{l}$. So the inequality above becomes:

$$
\frac{\overline{N^{h}} w_{2}^{u, h}+N^{l} q^{l}}{\overline{N^{h}} q^{h}+N^{l} q^{l}} \geq \frac{N^{h} w_{2}^{u, h}+N^{l} q^{l}}{\underline{N^{h} q^{h}+N^{l} q^{l}}}
$$

After some algebra this leads to $w_{2}^{u, h} \geq q^{h}$. But this inequality cannot hold, as it is always true that $w_{2}^{u, h}<q^{h}$, since $q^{h}$ is the highest possible wage. This gives the desirable contradiction. This shows that unskilled wages for inexperienced workers $\left(w_{1}^{u}\right)$ decrease more compared to the average unskilled wage for experienced workers $\left(w_{2}^{u}\right)$. That is why the experience premium increases only for low educated workers when higher education expands due to the relaxation of credit frictions.

The findings summarized in Propositions 3 and 4 find strong empirical support in the US over the past four decades (see Table 2). The main result of propositions 3 and 4 is that when higher education becomes more easily affordable by less severe credit constraints, wage inequality increases in a dual way, by raising both the education and the experience premium. Policies that expand educational opportunity such as a lower borrowing interest rates, actually raise wage inequality.

Figure 4 shows that less severe credit constraints, increase the slope of the supply curve and shift the whole supply curve inwards. In a stable equilibrium - where the slope of the supply curve exceeds that of the demand curve - this decreases unskilled inexperienced wages and so it raises the experience premium only for low educated workers, as well as the educated premium for experienced and inexperienced workers, since the denominator falls for these wage ratios. In unstable equilibria the results are reverted.

Table 2 in Section 3 illustrates the evolution of the education premium within experience group and the experience premium within educational group. The education premium increases for both experience groups, while the experience premium increases significantly within the group of high school graduates, while it does not have an increasing or a decreasing trend within the group of college graduates. Propositions 3 and 4 lead to the following corollary, which is supported by US data (see Table 2 in Section 3). 
COROLLARY 1: From propositions 3 and 4 we deduce that, when higher education expands due to the relaxation of credit constraints, the rise in the education premium is larger for low experienced workers compared to the group of highly experienced workers.

The validity of this result lies in the fact that the expansion of higher education due to a relaxation of credit constraints generates a larger decline in unskilled wages for inexperienced workers $\left(w_{1}^{u}\right)$, as this is displayed in Figure 4, compared to the average unskilled wage for experienced workers $\left(w_{2}^{u}\right)$. This result comes directly from the proof of proposition 4 . Additionally, we know that the skilled wages for inexperienced and for experienced workers are equal $\left(w_{2}^{s}=w_{3}^{s}=q^{h}\right)$ and remain unaltered. Therefore, the increase in the education premium for inexperienced workers $\left(w_{2}^{s} / w_{1}^{u}\right)$ is larger in magnitude compared to the increase in the education premium for experienced workers $\left(w_{3}^{s} / w_{2}^{u}\right)$, as the numerators do not change after college expansion but the denominator declines more for the former ratio compared to the latter. That is why the corollary holds.

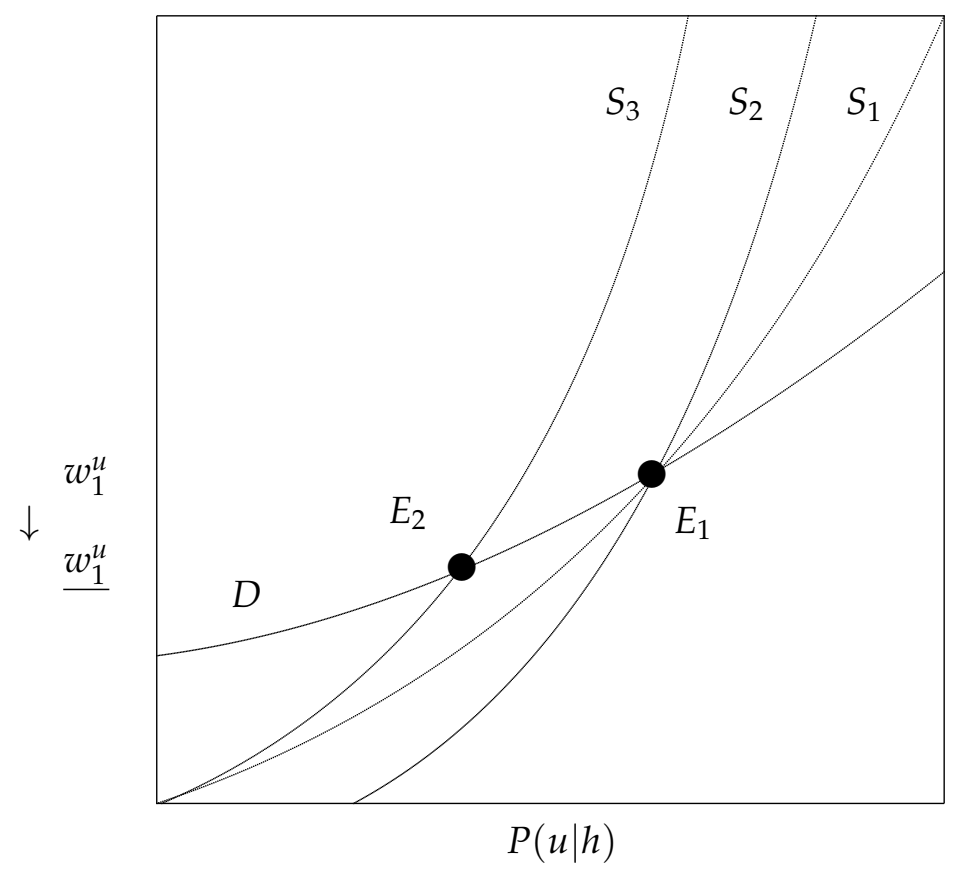

Fig. 4. Comparative Statics when Education Expands in a Stable Equilibrium

\subsection{Multiple Equilibria, Selection and Minimum Wage Policy}

In Figure 4 there is only one stable equilibrium before college expansion due to the relaxation of credit constraints $E_{1}$ and only one stable equilibrium after $E_{2}$. However, there can be multiple equilibria. When the supply curve intersects the demand curve from below, the equilibrium is stable, otherwise it is unstable. For instance, in Figure 2 there are three equilibria $A, B$ and $C$, of which only $A$ and $C$ are stable.

Minimum wage policy can affect the equilibrium outcome and ultimately wage inequality. This can be illustrated in Figure 2. Consider the three equilibria $A, B$ and $C$. If the minimum wage is set at a level above the one that corresponds to the unstable equilibrium $B$, the economy would reach the stable equilibrium $C$ that relates to a relatively high unskilled inexperienced wage, which in turn would keep wage inequality at a relatively low level. 
Alternatively, when the minimum wage is set below or equal to the level that corresponds to equilibrium $A$, the economy converges to the stable equilibrium $A$, which relates to a relatively low unskilled-inexperienced wage and therefore to higher wage inequality. For minimum wages above the level of equilibrium $A$ but below the wage of the unstable equilibrium $B$, the dynamic trajectory pushes the equilibrium to $A$ but the minimum wage distorts the market mechanism and does not allow the economy to reach this level. Thus, in this case the equilibrium cannot be determined and only after a shock the economy can reach the stable equilibrium at point $C$.

This offers an additional reason why the increase in wage inequality was large during the period 1970-1996, as both higher education has expanded (leading to a decline in unskilled inexperienced wages) and the real minimum wage has fallen (leading to a lower equilibrium unskilled-inexperienced wage). The finding that low minimum wages raise wage inequality is supported by several studies, which report a pattern of movements to the opposite direction between minimum wages and wage inequality. Lee (1999), Card and DiNardo (2002), and Teulings (2003) propose that the fall in real minimum wage is responsible for the rising wage inequality in the US. Machin (1997), and Machin et al. (2003) find similar results for the UK. DiNardo and Lemieux (1997) suggest that in the US the minimum wage fell significantly inducing a rise in wage inequality, while in Canada the more moderate decrease in the minimum wage caused a smaller increase in wage inequality. Autor et al. (2016) show that falling minimum wages raise wage inequality not only at the lower tail of the wage distribution but also at wage percentiles where the minimum is non-binding, which implies spillovers. ${ }^{28}$

\section{Evidence from the Current Population Survey}

One of the most important results from the theoretical analysis is that when college expands due to a relaxation in credit constraints, talented individuals can acquire education and leave the uneducated pool, unskilled inexperienced wages decline and this generates both an increase in the skill premium for inexperienced workers but also an increase in the experience premium for unskilled workers. This occurs as in both wage ratios the denominator declines. This section, examines whether this theoretical prediction finds empirical support, using data from the March Current Population Survey (CPS), a major data source representing the entire US labor market. First, I examine in detail the empirical facts that my study accounts for and then I show why the fall of unskilled inexperienced wages is crucial.

\subsection{My Empirical Approach: Data, Method and Results}

For my own calculations I use the March Current Population survey, which is constructed in order to be representative of the US labor market. I use individual data for real weekly earnings from 1963 to 2008, for white males aged 16 to 64 that work full-time, full-year, defined as 35-plus hours per week 40-plus weeks per year and who are not self employed. I also exclude those who have a real weekly wage below 67 US dollars (measured in 1982 US dollars). Our sample includes only the individuals who have completed basic education,

\footnotetext{
${ }^{28}$ Additionally, this result raises concerns related to unemployment, as governments might wish to decrease minimum wages to increase employment. A discussion on this tradeoff is beyond the scope of this study. However, Card and Krueger (1994), in one of the first empirical studies to examine this issue, show that decreasing minimum wages does not necessarily raise employment.
} 
which means at least high school completed (more than or equal to 12 years of education). As in Acemoglu and Autor (2011), real wage are deflated using Personal Consumption Expenditure Deflator, which shows lower inflation compared to the widely used Consumer Price Index.

We start our calculations with some descriptive analysis of the returns to education and experience. We follow the Mincerian (1974) approach with a linear and quadratic term for years of potential experience and we estimate the following equation:

$$
\log \text { Wage }_{i}=c_{0}+c_{1} \text { College }_{i}+c_{2} \text { Exp }+c_{3} \text { Exp }^{2}+c_{4} \text { Hours }_{i}+c_{5} \text { Weeks }_{i}+\text { Dummies }+e_{i}
$$

Table 1 below displays the estimated coefficients every decade. We observe a clear increase in the returns to education and experience, an increasing importance of the number of hours worked per week, while occupation sorting explains a large component of wage variation. ${ }^{29}$

Table 1. Mincerian Returns from Log Wage Regressions, White Males, US, 1970-2008.

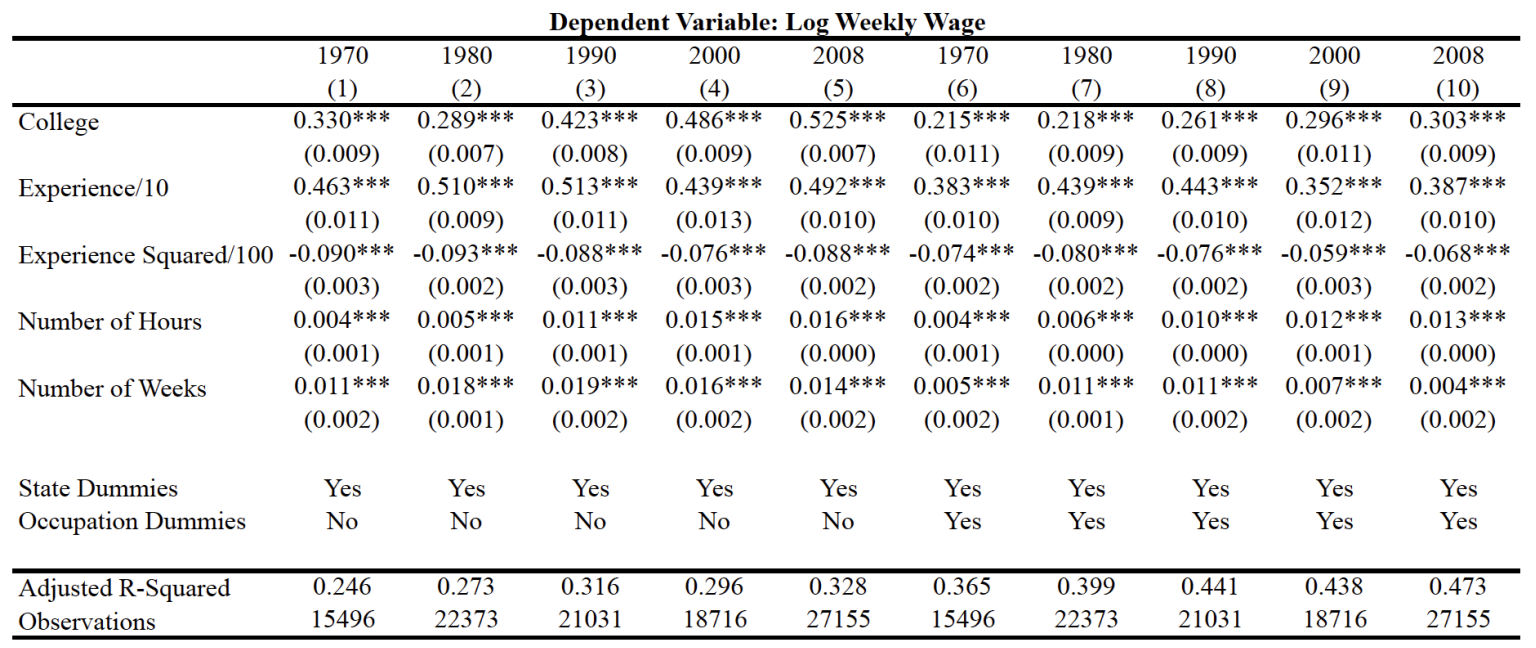

Note: This Table displays the coefficients from OLS Log Wage Mincerian regression for white males in the US, using the CPS. College is a dummy variable taking value 1 if at least college education is completed, otherwise 0 . Our sample includes only individuals who have at least high school completed, which means at least 12 years of education. Experience stands for years of potential experience, while we divide the linear term by 10 and the quadratic by 100, consistently with the previous literature. We control for hours worked per week, weeks worked per year and state dummies. Columns (1)-(5) exclude occupation dummies, while columns (6)-(10) include occupation dummies too. All regressions include a constant. Robust standard errors in parenthesis.

We calculate the education and the experience premium running log wage regressions for every year. Then we estimate the education premium within experience level and the experience premium within education level. For the calculation of each wage premium, in every regression we control for hours worked per week, weeks worked per year and state specific characteristics (further details appear in the online Appendix A1). For instance, the pooled education premium is derived by the coefficient $c_{1}$ when we run this regression for every year between 1963-2008:

$$
\log \text { Wage }_{i}=c_{0}+c_{1} \text { College }_{i}+c_{2} \text { Hours }_{i}+c_{3} \text { Weeks }_{i}+\text { Dummies }+e_{i}
$$

\footnotetext{
${ }^{29}$ Notice that Kambourov and Manovskii (2013) highlight that the March CPS data are characterized by a substantial amount of noise, as occupation dummies change frequently perplexing comparisons across time. This is the reason why we exclude occupation dummies when we calculate the time series of the wage premia.
} 
Where college is a variable which takes value 1 if the individual has at least completed college, otherwise is 0 . Notice that we also control for the number of hours worked per week, the number of weeks worked per year and for state specific effects. For the education premium for inexperienced workers we run the regression above but we restrict our sample for individuals with 0-9 years of potential experience. In accordance with the existing literature, for the education premium for experienced workers our sample includes only those with 20-29 years of experience.

In a similar way we calculate the experience premium within education group. Particularly the pooled experience premium is derived by the following low wage regression for every year between 1963-2008:

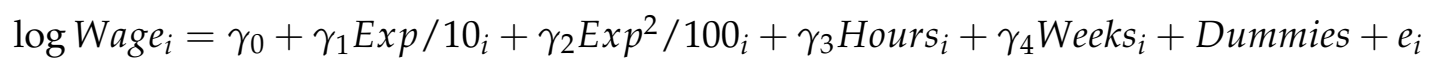

Where the experience variable includes years of potential experience, which is age minus education minus six. Again we include a series of control variables. For the experience premium for less educated workers we run the regression above but we restrict our sample for individuals with less than college education completed, which is less than 16 years of education. For the experience premium for highly-educated workers our sample includes those with at least college education, which is above than or equal to 16 years of education. The experience premium is derived by the estimated coefficients $\gamma_{1}$ for every year.

Table 2. Annual Trends for Wage Inequality, White Males, US, 1970-1996. Time Trends: Within Group Education and Experience Wage Premia, 1970-1996

\begin{tabular}{lcccccccc}
\hline & \multicolumn{4}{c}{ Log Education Premium } & & \multicolumn{3}{c}{ Log Experience Premium } \\
\cline { 2 - 4 } \cline { 6 - 8 } & All & Exper 0-9 & Exper 20-29 & & All & Educ $<16$ & Educ $>=16$ \\
& $(1)$ & $(2)$ & $(3)$ & & $(4)$ & $(5)$ & $(6)$ \\
\hline Year & $0.0035^{* * *}$ & $0.0092^{* * *}$ & $0.0038^{* *}$ & & $0.0020^{* *}$ & $0.0026^{* * *}$ & -0.0022 \\
& $(0.0005)$ & $(0.0010)$ & $(0.0014)$ & & $(0.0008)$ & $(0.0006)$ & $(0.0013)$ \\
Composition & $-0.3016^{* * *}$ & -0.1118 & 0.0041 & & $0.0513^{* *}$ & $-0.0579^{* *}$ & 0.0045 \\
& $(0.0417)$ & $(0.1094)$ & $(0.1037)$ & & $(0.0202)$ & $(0.0254)$ & $(0.0385)$ \\
\hline Adj. R squared & 0.91 & 0.722 & 0.573 & & 0.235 & 0.296 & 0.082 \\
Observations & 27 & 27 & 27 & & 27 & 27 & 27 \\
\hline
\end{tabular}

Note: Annual time trend from log wage premium OLS regressions within education-experience group for white males. Columns (1)-(3) correspond to the adjusted log wage ratio for the education premium, while columns (4)-(6) link to the adjusted log wage ratio for the experience premium. All regressions adjust for the relative supply of workers (composition effect). Columns (1) and (4) relate to all workers, while the other columns relate to particular education or experience groups, as specified in the table. The data correspond to the period 1970-1996. In the parentheses robust standard errors are displayed. Source: March Current Population Survey, US. Significance at the 1, 5, 10 percent significance level is indicated respectively by $* * * * *$ and *.

Table 2 takes these estimated coefficients and contrasts quantitatively the time trends of these log wage premia within different education-experience groups, deriving similar results. Even though the evolution of these premia over time is not linear, a simple linear analysis can yield some interesting results, especially during the period 1970-1996, while it would also allow us to test whether the predictions of the theoretical model are consistent with empirical evidence. In particular, columns (1) and (4) of Table 2 show that for the period 1970-1996 the pooled education premium and the pooled experience premium increase. Columns (2) and (3) illustrate that the education premium increases sharply for less experienced workers. 
Similarly, columns (5) and (6) display that the experience premium increases only for less educated workers, while it remains relatively flat for the highly educated ones. Notice that we control for the composition of workers in each education-experience group.

Recall Figure 1 which shows that during the period 1970-1996 the drop in unskilled inexperienced wages (denominator) was primarily responsible for the increase in both the education premium for inexperienced workers and the experience premium for less educated labor, which in turn accounted for most the rise in the pooled education and experience premium. In fact real wages for unskilled inexperienced workers, which is the denominator of these wage premia, declined by 21.8 percent between 1970 and 1996, while the numerators have not changed much.

\section{2. $\quad$ Comparing Falling Unskilled-Inexperienced Wages and Falling Unskilled Wages}

One of the new elements of the model is the examination of wage inequality within group. For instance, the education premium is studied within experience level. This serves two purposes. First, it shows that the evolution of the education premium is very different for inexperienced and for experienced workers. In fact, it rises sharply for the former, while it increases only moderately for the latter. The second purpose is that the most important prediction of the model - that the decline in the denominator (and not the rise in the numerator) increases the education premium - does not hold if we examine the pooled education premium for both experienced and inexperienced workers together, as Hendel et al. (2005) do in their influential paper.

I show this in two steps. First, panels A and B of Figure 5 depict the education premium for inexperienced workers and the education premium for both experienced and inexperienced workers being pooled together. The rise in both wage premia looks similar.

However, the second step shows that the evolution of the numerator and the denominator for each of these wage premia is different. Panel $C$ of Figure 5 shows that during the period 1970-1996 the education premium for inexperienced workers increases mainly because the denominator (unskilled inexperienced wages) falls, while the numerator (skilled inexperienced wages) does not change much over the same period. One can see this by comparing the left panels in Figure 5 (panels A and C). However, panel D of Figure 5 shows that this is no longer the case when all experience levels are grouped together, as the pooled education premium increases mainly because the numerator (skilled wages) raises and not due to the moderate decline of the denominator (unskilled wages). This can be illustrated by comparing the right panels in Figure 5 (panels B and D). ${ }^{30}$

Quantitatively, real wages for unskilled inexperienced workers, which is the denominator in panel C, declined by 21 percent between 1970 and 1996, and this increased the education premium for inexperienced workers, as the numerator has not changed much (actually it has increased only by 1.27 percent). In contrast, real wages for unskilled workers of any experience level, which is the denominator in panel $\mathrm{D}$, declined only by 6.25 percent between 1970 and 1996. At the same time real wages for skilled workers of any experience level, which is the numerator in panel $\mathrm{D}$, increased by 10.5 percent and therefore this increased mainly the pooled education premium. This suggests that my theory is consistent with empirical

\footnotetext{
${ }^{30}$ The series in panel A of Figure 5 displays the ratio of the numerator over the denominator, which we can see separately in panel C. Similarly, panel B of Figure 5 displays the ratio of the numerator over the denominator, which is illustrated separately in panel $\mathrm{D}$.
} 
evidence from the US, especially during the period 1970-1996. Nevertheless, this is not the case for models which ignore experience and focus on the pooled education premium.
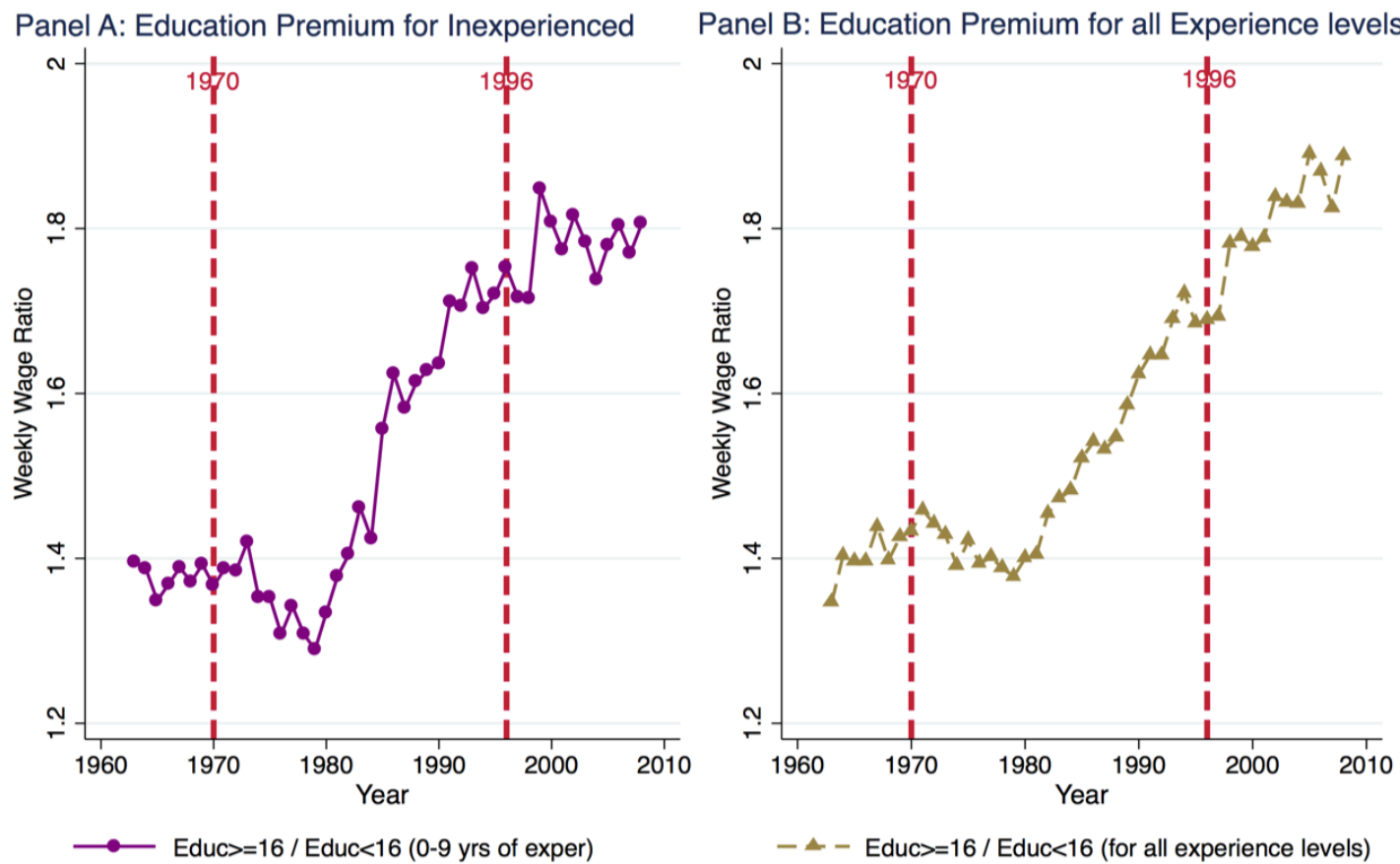

Panel C: Education Premium for Inexperienced

Panel D: Education Premium for all Experience levels
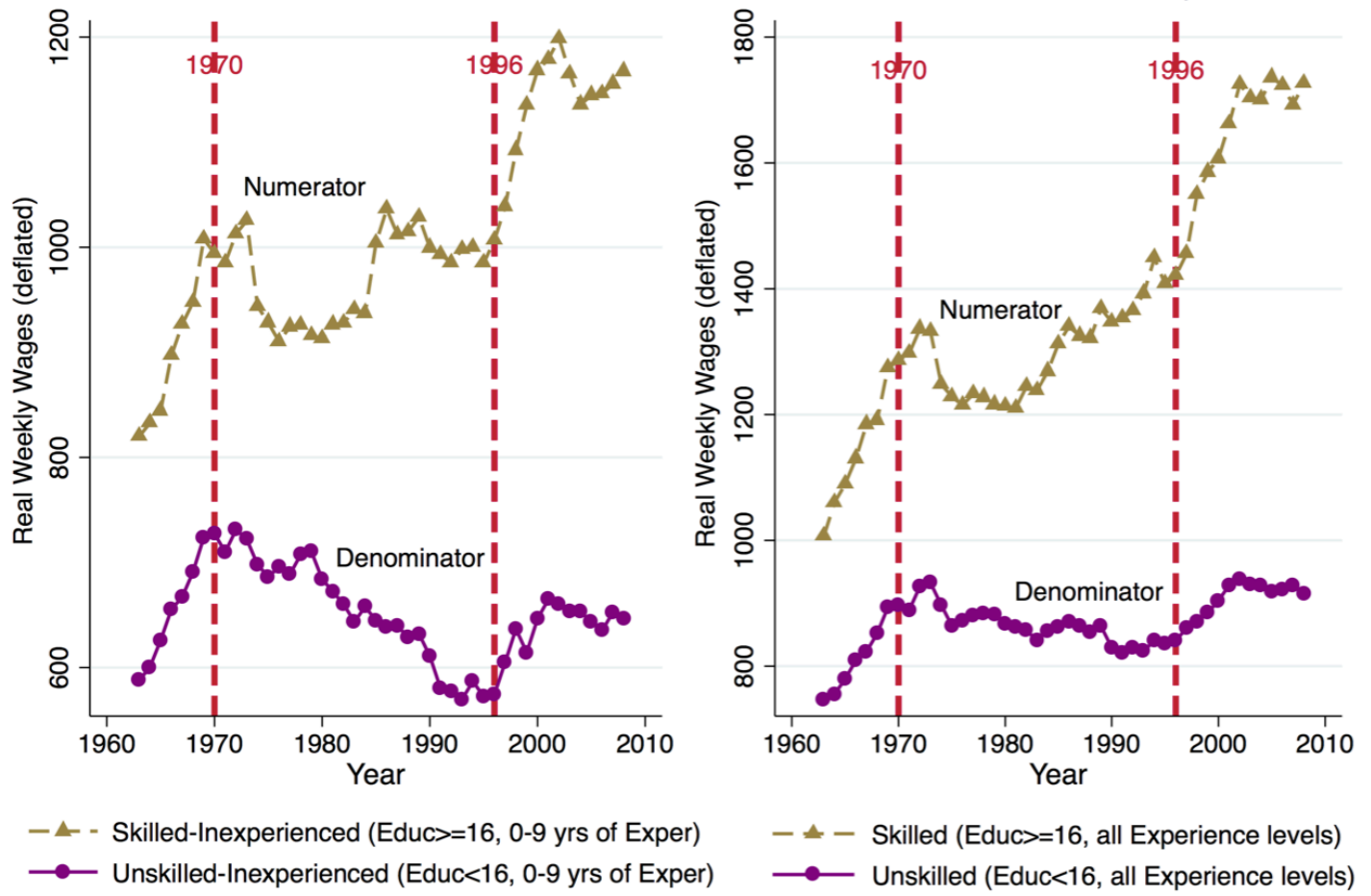

$-1-$ - Skilled-Inexperienced (Educ $>=16,0-9$ yrs of Exper)

$\longrightarrow$ Unskilled (Educ $<16$, all Experience levels)

Fig. 5. Numerator vs Denominator for Education Premium, White Males, CPS.

My model takes the main insight by Hendel et al. (2005), modifies it with the inclusion of the experience premium, which is driven by private employer learning and shows that the combination of signaling and asymmetric information not only provides a theoretical explanation for rising wage inequality but also that this explanation is empirically plausible. 


\subsection{Examining the Empirical Relevance of the Parameters from the Theoretical Model}

However, before moving forward we should reconsider carefully the theoretical part and check whether it is appropriate to extend it empirically. In order to perform the comparative statics exercise, all other parameters must remain constant when credit constraints relax. The most relevant parameter is the tuition cost, which I treat as being relatively flat over time. Is this an empirically plausible assumption between 1970 and 1996? Figure 6 indicates precisely this. In particular, Hoxby (2000) suggests that tuition fees for the average college have remained constant in real term between 1970 and 1996. Over this period most of the rise in the average tuition cost, has been driven mainly from large increases in few very expensive colleges, while for most colleges there was actually no change in real terms. This means that for the period 1970-1996 it is possible to perform the comparative statics exercise.

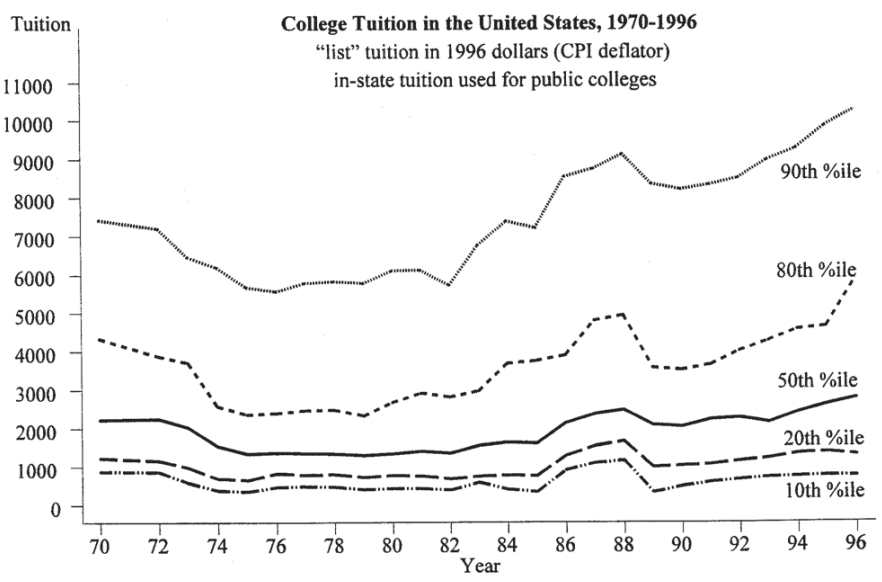

Fig. 6. Tuition Cost, 1970-1996, US.

Source. Hoxby (2000).

Also, Figures 7 and 8 show that credit constraints for education relax and that college education expands between the 1970s and the mid 1990s. In particular, the former figure displays federal loans as a percentage of GDP, while the latter illustrates the evolution of college continuation rates in the US.
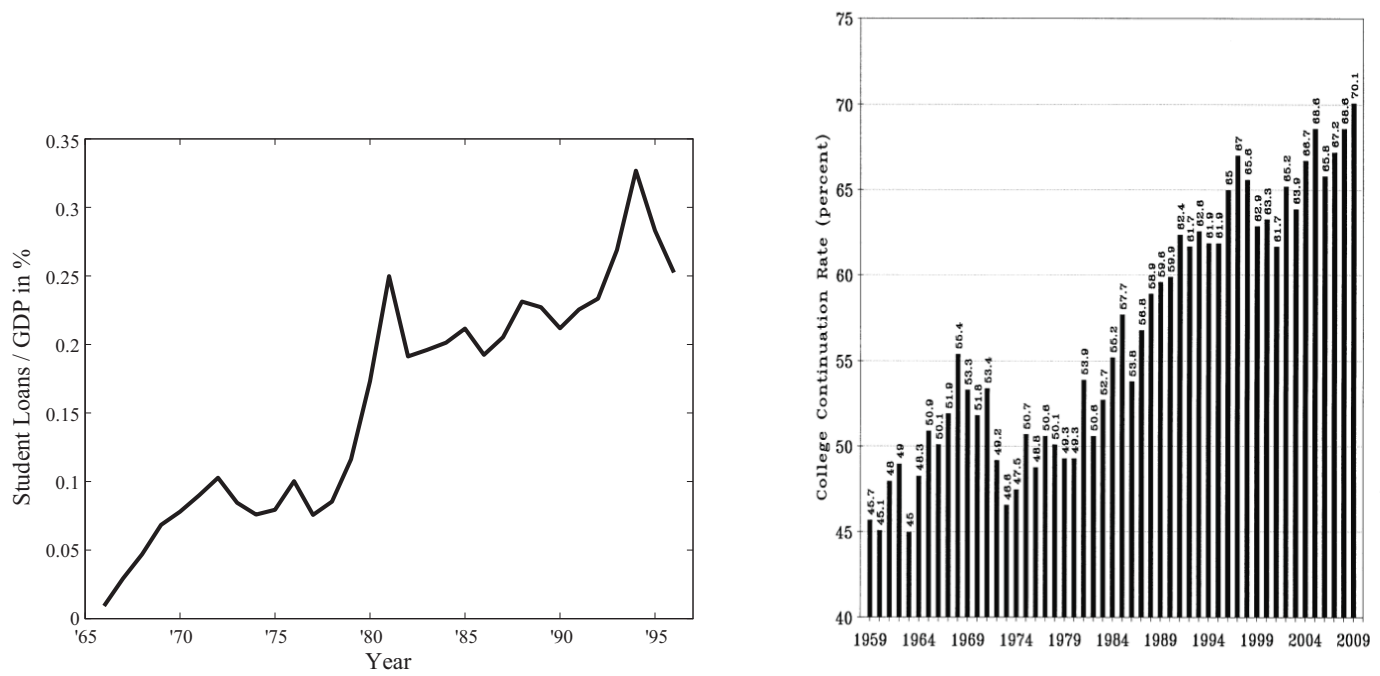

Fig. 7. Federal Student Loans/GDP.

Source. Hendel et al. (2005).

Fig. 8. \% going to college after high school. Source. Postsecondary Education Opportunity. 
Figures 1 and 5 show that the decline of the real wage for unskilled inexperienced workers almost coincides with the rise in the education premium for inexperienced workers and with the experience premium for unskilled workers, especially between 1970 and 1996 (indicated by the two vertical lines on each graph), when credit constraints have relaxed and college attendance have increased, as my study suggests. These facts are in perfect harmony with the theoretical model.

This evidence suggests that the theoretical explanation finds strong empirical support from the CPS and it is worthy examining some of its predictions more formally. In particular, a key result of the theoretical model is the decline in ability for the average unskilled inexperienced worker.

\section{Quantitative Analysis}

\subsection{Technology vs Sorting}

Consider the same economy with the only alteration that different education-experience groups enter as imperfect substitutes in the production function, which exhibits diminishing returns to labor inputs. There exist five such groups: unskilled inexperienced $(U, I)$, unskilled with some experience $(U, E)$, unskilled experienced $(U, E E)$, skilled inexperienced $(S, I)$ and skilled experienced $(S, E)$ workers. ${ }^{31}$ For each one of these groups labor exhibits diminishing returns, while production is linear (constant returns to scale) to composite labor, which is the only input. Formally, $Y=Z L$. Labor is divided into the five groups as follows and takes the form of constant elasticity of substitution (CES) and $L$ equals:

$$
L=\left[\left(A_{U, I} L_{U, I}\right)^{\sigma}+\left(A_{U, E} L_{U, E}\right)^{\sigma}+\left(A_{U, E E} L_{U, E E}\right)^{\sigma}+\left(A_{S, I} L_{S, I}\right)^{\sigma}+\left(A_{S, E} L_{S, E}\right)^{\sigma}\right]^{1 / \sigma}
$$

The marginal product of labor for each of these five groups is given below:

$$
\begin{gathered}
\frac{\partial Y}{\partial L_{U, I}}=Z(1 / \sigma)[\ldots]^{(1 / \sigma)-1} \sigma A_{U, I}^{\sigma} L_{U, I}^{\sigma-1} \equiv w_{1}^{u} \\
\frac{\partial Y}{\partial L_{U, E}}=Z(1 / \sigma)[\ldots]^{(1 / \sigma)-1} \sigma A_{U, E}^{\sigma} L_{U, E}^{\sigma-1} \equiv w_{2}^{u, P} \\
\frac{\partial Y}{\partial L_{U, E E}}=Z(1 / \sigma)[\ldots]^{(1 / \sigma)-1} \sigma A_{U, E E}^{\sigma} L_{U, E E}^{\sigma-1} \equiv w_{3}^{u, P} \\
\frac{\partial Y}{\partial L_{S, I}}=Z(1 / \sigma)[\ldots]^{(1 / \sigma)-1} \sigma A_{S, I}^{\sigma} L_{S, I}^{\sigma-1} \equiv w_{2}^{S}=q^{h} \\
\frac{\partial Y}{\partial L_{S, E}}=Z(1 / \sigma)[\ldots]^{(1 / \sigma)-1} \sigma A_{S, E}^{\sigma} L_{S, E}^{\sigma-1} \equiv w_{3}^{s}\left(=q^{h}\right)
\end{gathered}
$$

\footnotetext{
${ }^{31}$ The average unskilled worker can acquire more experience as he enters the labor market earlier compared to the skillededucated worker, who sacrifices some years of potential experience for schooling.
} 
Recall that Total Factor Productivity (TFP), denoted by $A$ in the equations above, is the portion of output which is not explained by the quantity of labor inputs used in production. This paper argues that the quality of labor inputs as defined by different education and experience groups is not constant and depends on the quantity of individuals who can acquire higher education and of their average ability.

The log of the marginal rate of transformation gives the log of the wage premium. What appears inside the brackets in equation (18), which is denoted as [...] in equations (19)-(23), cancels out when we take the log of the marginal rate of transformation. Equation (22) over (19) gives the skill premium for inexperienced workers, which can be seen in equation (24).

$$
\ln M R T_{S I, U I}=\ln \frac{w_{2}^{S}}{w_{1}^{u}}=\sigma \ln \frac{A_{S, I}}{A_{U, I}}-(1-\sigma) \ln \frac{L_{S, I}}{L_{U, I}}
$$

According to the skill-biased technical change (SBTC) approach, the skill premium increased because technology favours the relatively more educated workers. This explanation treats each education-experience group as being of the same quality over time. An increase in the skill premium for inexperienced workers requires an increase in the fraction $A_{S, I} / A_{U, I}$ which is larger than the increase in the relative supply of skills $L_{S, I} / L_{U, I}$. This directed technical change generates two effects. The demand effect, which increases the skill premium, as firms ask for more skills due to the skill bias of technical change and the supply effect, which moves to the opposite direction and decreases the relative wages for skilled workers due to the rise in the relative supply (relative quantity) of skills. This logic can be seen below:

$$
S B T C: \ln M R T_{S I, U I}=\ln \frac{w_{2}^{s}}{w_{1}^{u}} \uparrow=\sigma \ln \frac{A_{S, I}}{A_{U, I}} \uparrow-(1-\sigma) \ln \frac{L_{S, I}}{L_{U, I}} \uparrow
$$

My model of sorting suggests a complementary explanation based on the composition of unobservables, such as ability, to groups of observables, such as education-experience categories. My approach allows the quality of education-experience groups to change over time. In fact, I show that an increase in the access of higher education allowed talented individuals to go to college and leave the uneducated pool. This decreased the average quality of unskilled inexperienced workers $A_{U, I}$, decreased unskilled inexperienced wages $w_{1}^{u}$ and in turn boosted wage inequality, despite the rise in the relative supply of skills $L_{S, I} / L_{U, I}$, which decreases the relative wages for skilled workers. My explanation suggests that changes in the composition of skills generate two effects. The quality effect, which boosts the skill premium for inexperienced workers due to a decline in the quality (ability) of unskilled inexperienced workers and the quantity effect, which decreases the skill premium for inexperienced workers due to the increase in the relative quantity (relative supply) of skills. This logic can be seen below:

$$
\text { Sorting }: \ln M R T_{S I, U I}=\ln \frac{w_{2}^{s}}{w_{1}^{u} \downarrow}=\sigma \ln \frac{A_{S, I}}{A_{U, I} \downarrow}-(1-\sigma) \ln \frac{L_{S, I}}{L_{U, I}} \uparrow
$$

Acemoglu and Autor (2012) highlight that "another fact that underscores the shortcomings of the canonical model is the surprising evolution of real (rather than relative) wage levels." Precisely this is the main difference between the two approaches, as the canonical SBTC model explains changes in relative wage levels, while my model explains the patterns of real 
wages in absolute terms, offering a new complementary explanation to the SBTC approach. This explanation is consistent with US wage data from the CPS indicating that the rise in the skill and the experience premium is driven by the fall in unskilled inexperienced wages, while at the same time skilled or experienced wages remain constant. Thus, it seems that between 1970-1996 my theory finds strong empirical support.

We can also compare my sorting approach with Caselli's (2015) experience-biased technical change (EBTC) one. The main prediction of my model that the decline in unskilled inexperienced wages drives the rise in the experience premium, holds again (see Figure 1). My model focuses on supply factors and provides a new unified explanation for the increase in the education and the experience premium (despite the growing supply of skills) and thus justifies the facts that jointly the SBTC and the EBTC approaches explain. Nevertheless, my supply side framework complements these two approaches, which are based primarily on the demand side and in particular on the role of technology-skill complementarities.
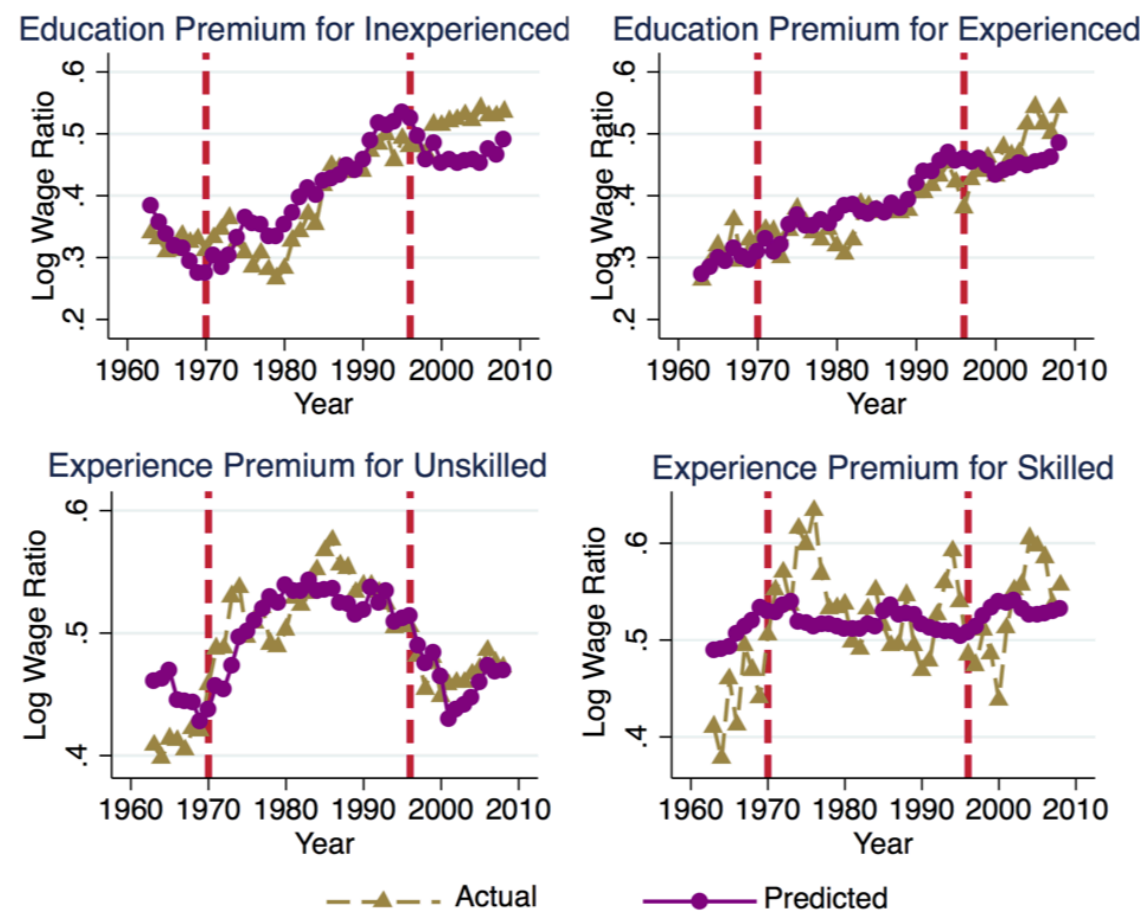

Fig. 9. The fit of the model, White Males, CPS.

Fit of the Theoretical Model.-It is interesting to examine the fit of the model, as this is described above. For the education premium for inexperienced workers we estimate (27).

$$
\ln \omega_{t}=c_{1} \ln w_{t}^{u, i}+c_{2} \ln \frac{L_{U, I}}{L_{S, I} t}+c_{3} \text { year }_{t}+\text { error }_{t}
$$

This is based on (26) but it replaces the productivity of unskilled inexperienced workers $A_{U, I}$ with the wage of this group and it treats the productivity of skilled inexperienced workers as constant $A_{S, I}$, while the depend variable is the education premium denoted by $\omega$.

This regression is for the education premium for inexperienced workers. Following the same methodology we estimate regressions based on the other three wage premia. Figure 9 
contrasts the actual and the predicted wage premia for the four education-experience groups. It seems that our model fits nicely the data, especially during the period 1970-1996.

\section{Discussion}

Wage Decline for Unskilled Inexperienced Workers.-This study not only provides a microfounded explanation for some key wage inequality facts but also it reveals that the decline in unskilled inexperienced wages (denominator) is the common factor that accounts for both the rise in the education premium for inexperienced workers and the rise in the experience premium for uneducated labor, which in turn are responsible for most of the rise in the pooled education and experience premia. Figure 10 highlight this. Notice the sharp decline in the common denominator during 1970-1996, which is measured in the right vertical axis. This prediction is the main result of the theoretical model, which finds strong empirical support in the US using CPS wage data. Also, recall Figure 5 which compares the sharp decline in unskilled inexperienced wages to the moderate fall in unskilled wages for all experience groups and clearly shows that decomposing unskilled wages by experience level is a crucial distinguishing feature of this study compared to the existing literature, which has overlooked this important aspect of rising wage inequality in the US.

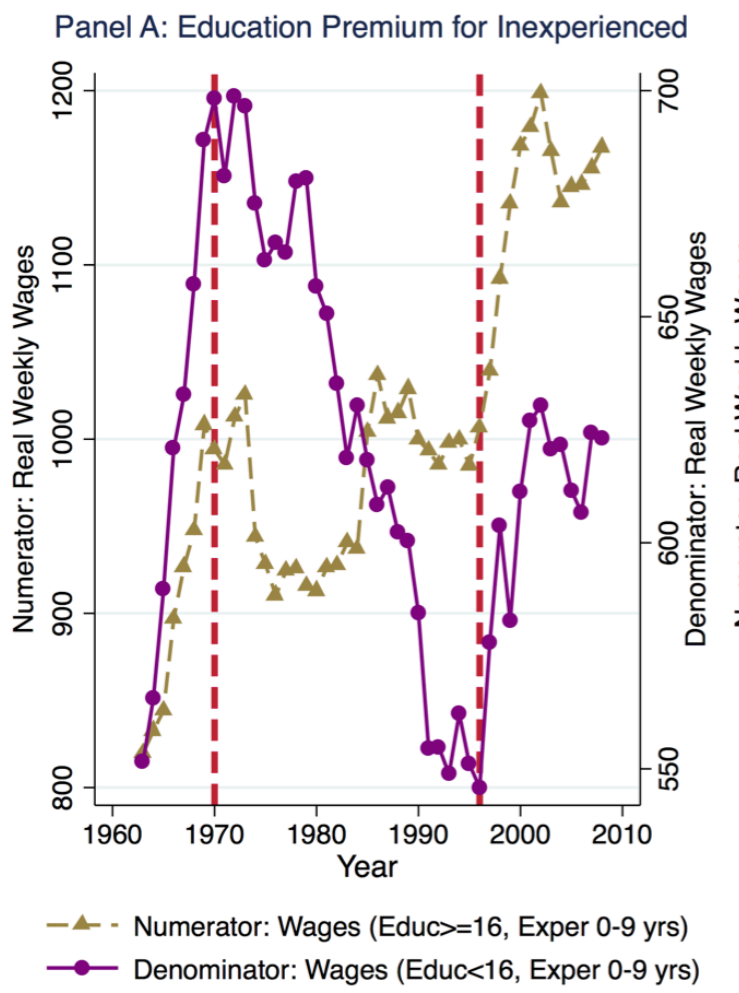

Panel B: Experience Premium for Uneducated

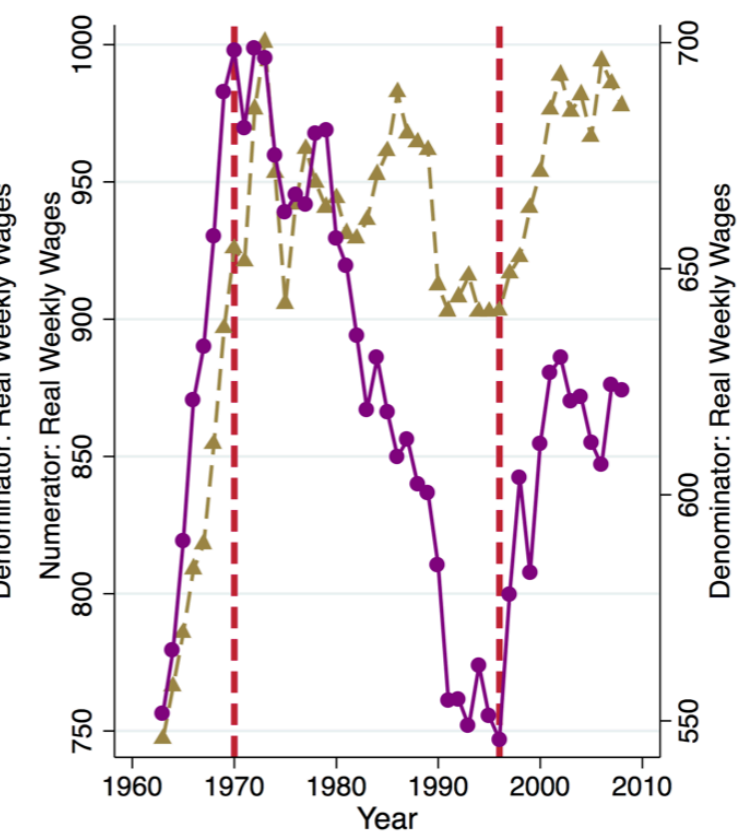

- - Numerator: Wages (Educ<16, Exper 20-29 yrs)

Fig. 10. Falling Unskilled Inexperienced Wages (Denominator), White Males, CPS.

Human Capital.-Apart from offering information for unobservable ability, higher education also increases labor productivity. Even though this is an important point, I abstract from it to keep the framework simple and clarify the signaling aspect of education that drives the results of this paper. However, the inclusion of human capital not only leaves the qualitative results of this study (propositions 3 and 4) unaffected but it also boosts further the magnitude of the increase in the skill premium, as not only unskilled wages drop but 
also skilled wages raise, widening further the wage gap. However, the results of the paper hold, even when the signaling approach is combined with human capital.

Learning-by-Doing ( $L B D)$.- - It is also true that workers learn by doing and this increases their productivity. However, my model abstracts from this element, as labor productivity is constant for the entire life of each agent ( $q^{l}$ for the low types and $q^{h}$ for the high types). I can easily extend the model and augment it with learning-by-doing by introducing a law of motion for labor productivity: $q_{t+1}^{j}=\lambda^{j} q_{t}^{j}$, where $t=1,2, j=\{l, h\}$ and $\lambda^{j}>1$. We can even allow LBD to take a quadratic form, which would give a more realistic concave profile for wages over the life-cycle. Also, following the terminology of Section 4.2, for unskilled workers Learning-By-Doing (LBD) implies that: $A_{U, E E} \geq A_{U, E} \geq A_{U, I}$, with equality if there is no LBD. Similarly for skilled workers $A_{S, E} \geq A_{S, I}$. In this case, LBD would affect the level of wage premia but not the changes in response to an expansion in higher education due to a relaxation of credit constraints. This implies that propositions 3 and 4 would be valid even if we augment the signaling model with LBD.

Minimum Wages.- - In the model presented above, without human capital, it seems that the lowest wage or the minimum wage is not the initial wage of the unskilled worker with zero experience $w_{1}^{u}$ but the wage of the low type unskilled worker with one year of experience, which is $w_{2}^{u, l}=q^{l}$. However, this is neither empirically plausible nor my model argues that wages can also decrease with experience. I propose that there can be a negative return to experience due to employer learning for workers with low ability. In general, economists observe that wages increase over the life-cycle generating a concave wage profile. This total change depends on two separate effects moving potentially to opposite directions.

Under asymmetric information competitive firms offer to the entire pool of unskilled workers a wage that equals their marginal productivity, say $w_{1}^{u}$. Then for the uneducated workers there is a dual influence on their wages. On one hand, there is a return to experience due to employee learning (learning-by-doing), which is always positive. On the other hand, there is a return to experience due to employer learning, which is positive for the uneducated high types and negative for the uneducated low types. Consider an unskilled low type. In the first period competitive firms offer a wage $w_{1}^{u}$, even for the low types who produce only $q^{l}$, which is lower than his wage $q^{l}<w_{1}^{u}$. If a firm offers a lower wage than $w_{1}^{u}$, other firms will attract all the low and high type uneducated workers. But notice that all firms wish to employ uneducated high types in the first period, since during the second period they derive a profit from those workers. In the second period there are two effects on the wage of a low type: a negative return to experience due to employer learning and a positive return to experience due to learning-by-doing. If the latter outweighs the former, it would not be clear to an econometrician whether the first effect even exists, since the observed pattern would be an increase in wages over the life-cycle. However, there are empirical papers addressing this issue and they find strong evidence for employer learning. In particular, they find an effect of ability test scores on wages*experience (see Arcidiacono et al., 2010). My theory proposes that the concave profile of wages over the life-cycle, conceals different effects moving potentially to opposite directions.

According to Figure 7, since the 1970s credit constraints relaxed significantly and rendered higher education more easily accessible. This in turn increased the college continuation rates 
(see Figure 8) and left a smaller faction of talented individuals who cannot attend college. Since educational opportunity increased, firms interpret the lack of college education as a clearer indication of low talent and offer lower initial wages to the remaining unskilled inexperienced workers, which boosts wage inequality.

Notice however, that this endogenously determined initial wage can decrease only if the legislation allows it, by setting the exogenous real minimum wage at a lower level, which is exactly what happened in the US. During the period 1981 to 1989 US authorities allowed this decline in the minimum wage by being passive and keeping the nominal minimum wage at 3.35 dollars per hour despite the rising inflation. This generated a mirror image between the declining real minimum wage and the rising labor income inequality (see Card and DiNardo, 2002), a pattern that finds strong empirical support in the US and many other countries.

Therefore, a realistic version of this signaling model, augmented with learning-by-doing, implies that the lowest wage is indeed the initial wage of the unskilled inexperienced worker $w_{1}^{u}$ and a reduction of this wage will increase wage inequality. As we have shown in Section 2.1, the falling real minimum wage is an additional reason why the increase in wage inequality was so large during the period 1970-1996, as both higher education has expanded (leading to a decline in unskilled inexperienced wages) and the real minimum wage has fallen (leading to a lower equilibrium unskilled inexperienced wage). This is an important theoretical result that finds empirical support. My finding is in line with Card and DiNardo (2002), who support that the early rise in inequality may have been due to rapid technological change, however the increase during the early 1980s is primarily attributed to the falling wages at the lower end of the distribution. Unambiguously, several determinants of wage inequality had an important impact during the past four decades but it seems that this study offers a new plausible explanation, especially during the period 1970-1996. ${ }^{32}$

However, the mere fall of the minimum wage, which occurred from 1978-1989, cannot account for the rise in wage inequality, which extends to a longer period. Unskilled inexperienced wages declined sharply during the period 1970-1996, when a large fraction of the increase in wage inequality occurred. The theoretical model suggests that the falling unskilled inexperienced wages drive the rise in wage inequality. Figure 5 shows that this is the case, especially for the period 1970-1996, when there was a mirror image between rising inequality and falling unskilled inexperienced wages.

College Expansion, Tuition, Student Finance E Loans.-My explanation suggests that since 1970s higher education expanded, as credit constraints became less severe. This is in harmony with US evidence on the increasing volume of loans as a percentage of GDP (see Figure 7). I argue that the easing of financial constraints, rendered education more easily accessible despite the rising tuition cost. According to Hoxby (2000) the increases in average tuition cost are driven by increases in few of the most expensive universities, while the majority of students attend colleges that have lower average fees and where inflation-adjusted tuition growth has been much more moderate. She argues that for half of the US universities the tuition cost in real terms remained unchanged between 1970 and 1996, which is the period that I am primarily interested in (see Figure 6). The relaxation of credit constraints increased educational opportunities and college continuation rates (see Figure 8) and left only few

\footnotetext{
${ }^{32}$ See also Beaudry et al., (2013), which suggests that from around the year 2000 onwards the demand for skills and labor markers have changed greatly.
} 
high type agents unskilled. Firms reacted to this by offering lower wages to unskilled and inexperienced workers, which in turn boosted wage inequality (see Figure 5).

The Key Analogy.-The ratios below describe how changes in wages for each educationexperience group determine the evolution of wage premia. The first equation in (28) explains that the experience premium increases only for less educated workers, while the education premium increases for both inexperienced and for experienced workers but the increase in the former is larger (these trends are contrasted quantitatively in Table 2). The second equation illustrates with arrows the changes in these wages, while the exact percentage change in the wages for each education-experience group can also be seen in Table 3 below.

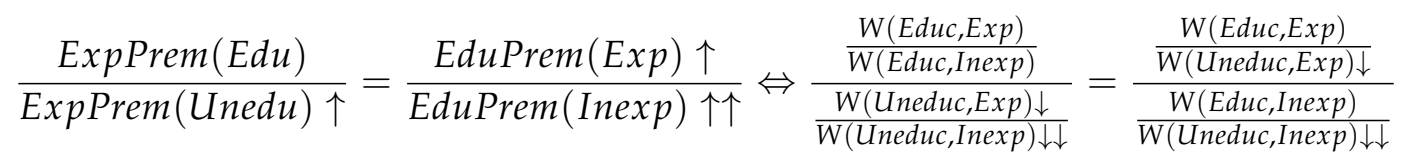

Two observations are worth noting. If we rearrange the wages in the equation of the right hand side in (28), we can clearly see why the equality holds and why this is equivalent to the left hand side equation in (28). Also, all these changes in the real wages are in perfect harmony with the theoretical model, especially during the period 1970-1996. ${ }^{33}$

Table 3. Changes in Wages for each Education-Experience Group, White Males, US, 1970-1996.

\begin{tabular}{ccccc}
\hline Year & W(Educ,Inexp) & W(Uneduc,Inexp) & W(Educ,Exp) & W(Uneduc,Exp) \\
\hline $\mathbf{1 9 7 0}$ & 994 & 727 & 1497 & 1018 \\
$\mathbf{1 9 9 6}$ & 1007 & 574 & 1546 & 955 \\
\hline \% change 1970-1996 & $1.27 \%$ & $-21.01 \%$ & $3.23 \%$ & $-6.19 \%$ \\
\hline
\end{tabular}

Table 3 displays the change in the average real weekly wage for each education-experience group using data come from the CPS. Notice that two changes stand out: the sharp decline in unskilled inexperienced wages and the fall in unskilled experienced wages. It is true that the percentage changes in the other two wage series is not exactly zero but undoubtedly it is insignificant compared to the two large drops.

\section{Conclusions}

This paper examines the perplexing coexistence of college expansion and wage inequality growth. The economic intuition behind most of the results of this paper is that without knowing the productivity of each person, competitive firms form beliefs about their potential employees and pay them according to their expected productivity. When higher education is less easily accessible, unskilled workers are more likely to be talented but incapable of acquiring college education. Nevertheless, as higher education becomes more easily affordable, highly productive individuals find it easier to access college and thus fewer of them remain uneducated. In this case firms interpret the lack of college education as a clearer indication of low talent and offer lower wages to the remaining unskilled inexperienced workers, which boosts wage inequality. This logic justifies why firms used to offer higher wages to unskilled inexperienced workers and why between 1970 and 1996, when higher

\footnotetext{
${ }^{33}$ Notice also that relationship (28) is consistent with the analysis performed by Jeong et al., (2015).
} 
education expanded, real wages for unskilled inexperienced labor have declined sharply. Yet, this smaller fraction of highly productive individuals who cannot acquire a higher education degree, receive a larger return to experience, as their starting wage is substantially compressed. This means that not only formal signals, such as college degrees, generate larger wage benefits when education expands but also informal learning, such as private employer learning via work experience, has a stronger impact on wages.

Previous studies mainly focus on the education premium when all experience groups are pooled together. This simplification masks the process whereby the education premium increases sharply for less experienced workers and moderately for the highly experienced ones. Similarly, the experience premium grows significantly and most of the previous studies either ignore this aspect of rising inequality or they examine the experience premium for all education groups jointly. This conceals the fact that the experience premium increases mainly for less educated workers. My study explains how wage inequality evolves within different education-experience groups, revealing that the expansion of higher education in the US during the 1970s, the 1980s and the 1990s, has allocated talent better in education by allowing talented but poor individuals to go to college. This has an important effect on society. In fact, it implies that the eventual group of uneducated young workers becomes of lower average quality because most of the rough diamonds have been plucked out of this group. In response, firms offer lower wages to the remaining workers of this unskilled and inexperienced group, which ultimately increases wage inequality.

This model of signaling, credit constraints and private employer learning fits US data well, especially during the period 1970-1996. Related studies, which focus on the pooled education premium find weak empirical support in the US, as the decline in unskilled wages for all experience groups is much smaller in magnitude, while it also coincides with the sharp rise of skilled wages, which is the main driver of the rising skill premium. Importantly, this theory provides a new explanation for the evolution of within group wage inequality and explains wage changes not only in relative but also in absolute terms. These are important features, which have been overlooked by the existing literature.

An interesting policy implication relates to the potential conflict between higher education access and wage inequality, suggesting that policy makers must clearly distinguish the one from the other. The fact that college expansion can actually increase inequality and this in turn can lead to less accessible higher education for future generations, highlights the vicious circle associated with the nature of inequality and the complexity of policy-making. This combined with the recent increases in tuition fees in many countries and especially in the US and in the UK, contribute to the topical debate regarding the recent stagnation of college completion. Additionally, in the presence of multiple equilibria, the determination of the level of minimum wage becomes essential. This study also shows that through minimum wages, policy makers can influence unskilled inexperienced wages and therefore the level of wage inequality.

This paper focuses mainly on the role of labor supply and provides a microfounded reasoning for recent macroeconomic facts related to rising wage inequality. Yet, there is a large body of literature on the skill-biased technical change, which emphasizes the demand side. The two approaches are complementary, as together they seem to provide a better understanding of the laws that determine labor income distribution than each approach alone. Ultimately, this study contributes to the main economic problem regarding the 
allocation of resources and offers a new explanation for some perplexing patterns of growing wage inequality, which finds strong empirical support and yields some interesting policy implications. Nevertheless, this paper just initiates an ambitious agenda, as there are several puzzling patterns in the wage structure which remain unexplained. Unambiguously, there is a promising avenue for future research on the interaction talent misallocation and wage inequality, which can increase our understanding regarding these complex social phenomena.

\section{References}

Acemoglu, Daron. (1998). "Why Do New Technologies Complement Skills? Directed Technical Change And Wage Inequality." Quarterly Journal of Economics 113 (4): 1055-1089.

Acemoglu, Daron. (2002). "Technical Change, Inequality, and the labor Market." Journal of Economic Literature 40 (1): 7-72.

Acemoglu, Daron, and David Autor. (2011). "Skills, Tasks and Technologies: Implications for Employment and Earnings." In Handbook of Labor Economics, edited by Orley Ashenfelter and David Card, 1043-1171. Elsevier.

Acemoglu, Daron, and David Autor. (2012). "What Does Human Capital Do? A Review of Goldin and Katz's The Race between Education and Technology." Journal of Economic Literature 50 (2): 426-463.

Aghion, Philippe, Peter Howitt, and Giovanni L. Violante. (2002). "General Purpose Technology and Wage Inequality." Journal of Economic Growth 7 (4): 315-45.

Allais, Maurice. (1947). Economie et Intérêt, Paris: Imprimerie Nationale.

Altonji, Joseph. (2005). “Employer Learning, Statistical Discrimination and Occupational Attainment." American Economic Review 95 (2): $112-$ 117.

Altonji, Joseph, and Charles Pierret. (2001). "Employer Learning And Statistical Discrimination." Ouarterly Journal of Economics 116 (1): $313-350$.

Autor, David, Lawrence Katz, and Melissa Kearney (2008). "Trends in US Wage Inequality: Revising the Revisionists." Review of Economics and Statistics 90(2): 300-323

Autor, David, Alan Manning, and Christopher Smith. (2016). “The Contribution of the Minimum Wage to U.S. Wage Inequality over Three Decades: A Reassessment." American Economic Journal: Applied Economics 8(1): 58-99.

Balleer, Almut, and Thijs Van Rens. (2013). "Skill-Biased Technological Change and the Business Cycle." Review of Economics and Statistics 95 (4): 1222-1237.

Banerjee, Abhijit, and Andrew Newman. (1993). “Occupational Choice and the Process of Development." Journal of Political Economy 101 (2): 274-98.

Bauer, Thomas, and John Haisken-DeNew. (2001). “Employer Learning and the Returns to Schooling." Labour Economics 8 (2): 161-180.

Bayer, Patrick, Peter Arcidiacono, and Aurel Hizmo. (2010). "Beyond Signaling and Human Capital: Education and the Revelation of Ability." American Economic Journal: Applied Economics 2 (4): 76-104.

Beaudry, Paul, David A. Green, and Benjamin Sand. (2016). "The Great Reversal in the Demand for Skill and Cognitive Tasks." Journal of Labor Economics 34(S1), S199-S247.

Becker, Gary. (1964). Human Capital: A Theoretical and Empirical Analysis, with Special Reference to Education. Chicago: University of Chicago Press.

Bedard, Kelly. (2001). "Human Capital versus Signaling Models: University Access and High School Dropouts." Journal of Political Economy, 109 (4): 749-775.

Berman, Eli, John Bound, and Stephen Machin. (1998). “Implications of Skill-Biased Technological Change: International Evidence.” Quarterly Journal of Economics 113 (4): 1245-1279.

Berman, Eli, and Stephen Machin. (2000). "Skill-biased Technology Transfer Around the World." Oxford Review of Economic Policy 16 (3): $12-22$.

Buera, Francisco J., and Joseph P. Kaboski. (2012). "The Rise of the Service Economy." American Economic Review 102 (6): $2540-2569$.

Card, David. (2001). "Estimating the Return to Schooling: Progress on Some Persistent Econometric Problems." Econometrica 69 (5): $1127-60$.

Card, David. (2009). "Immigration and Inequality." American Economic Review 99 (2): 1-21.

Card, David, and John DiNardo. (2002). "Skill-Biased Technological Change and Rising Wage Inequality: Some Problems and Puzzles." Journal of Labor Economics 20 (4): 733-783.

Card, David, and Alan Krueger. (1994). "Minimum Wages and Employment: A Case Study of the Fast-Food Industry in New Jersey and Pennsylvania." American Economic Review 84 (4): 772-793.

Card, David, and Thomas Lemieux. (2001). "Can Falling Supply Explain the Rising Return to College for Younger Men? A Cohort-Based Analysis." Quarterly Journal of Economics 116 (2): 705-746.

Card, David, Thomas Lemieux, and Craig Riddell. (2004). “Unions and Wage Inequality.” Journal of Labor Research, 25 (4): $519-562$.

Carneiro, Pedro, and James J. Heckman. (2002). "The Evidence on Credit Constraints in Post-Secondary Schooling." Economic Journal 112 (482): 705-734.

Caselli, Francesco. (1999). “Technological Revolutions.” American Economic Review 89 (1): 78-102.

Caselli, Francesco. (2015). "Experience-Biased Technical Change." CEPR Discussion Paper 10752.

Chevalier, Arnaud, Colm Harmon, Ian Walker, and Yu Zhu. (2004). "Does Education Raise Productivity, or Just Reflect it?" Economic Journal 114 (499): F499-F517.

Cho, In-Koo, and David Kreps. (1987). “Signaling Games and Stable Equilibria." Quarterly Journal of Economics 102 (2): $179-221$.

Ciccone, Antonio, and Elias Papaioannou. (2009). "Human Capital, the Structure of Production, and Growth." Review of Economics and Statistics 91(1): 66-82.

Diamond, Peter. (1965). "National Debt in a Neoclassical Growth Model." American Economic Review 55 (5): 1126-1150.

Dooley, Martin, and Peter Gottschalk. (1984). "Earnings Inequality among Males in the United States: Trends and the Effect of labor Force Growth." Journal of Political Economy 92 (1): 59-89.

Dustmann, Christian, and Costas Meghir. (2005). "Wages, Experience and Seniority." Review of Economic Studies 72 (1): 77-108.

Farber, Henry, and Robert Gibbons. (1996). "Learning and Wage Dynamics." Quarterly Journal of Economics 111 (4): $1007-1047$.

Galor, Oded, and Omer Moav. (2000). "Ability Biased Technological Transition, Wage Inequality and Economic Growth." Quarterly Journal of Economics 115 (2): 469-497.

Galor, Oded, and Joseph Zeira. (1993). “Income Distribution and Macroeconomics.” Review of Economic Studies 60 (1): 35-52. 
Goldin, Claudia, and Lawrence Katz. (2007). “Long-Run Changes in the Wage Structure: Narrowing, Widening, Polarizing." Brookings Papers on Economic Activity 38 (2): 135-168.

Gottschalk, Peter. (1997). “Inequality, Income Growth, and Mobility: The Basic Facts." Journal of Economic Perspectives 11 (2): $21-40$.

Gould, Eric., Omer Moav, and Bruce Weinberg. (2001). "Precautionary Demand for Education, Inequality and Technological Progress." Journal of Economic Growth 6 (4): 285-316.

Guvenen, Fatih. (2007). “Learning Your Earning: Are Labor Income Shocks Really Very Persistent?” American Economic Review 97 (3): 687-712.

Guvenen, Fatih, and Burhanettin Kuruscu. (2010). "A Quantitative Analysis of the Evolution of the US Wage Distribution, 1970-2000." In NBER Macroeconomics Annual, Volume 24, pp. 227-276.

Harrison, Ann, John McLaren, and Margaret McMillan. (2011). "Recent Perspectives on Trade and Inequality." Annual Review of Economics 3 (1): 261-289.

Haefke, Christian, Marcus Sonntag, and Thijs van Rens. (2013). “Wage Rigidity and Job Creation." Journal of Monetary Economics 8 (60): $887-899$.

Heathcote, Jonathan, Fabrizio Perri, and Giovanni L. Violante. (2010). "Unequal we stand: An Empirical Analysis of Economic Inequality in the United States, 1967-2006." Review of Economic Dynamics 13 (1): 15-51.

Heathcote, Jonathan, Kjetil Storesletten, and Giovanni L. Violante. (2010). "The Macroeconomic Implications of Rising Wage Inequality in the United States." Journal of Political Economy 118 (4): 681-722.

Heckman, James J., Lance Lochner, and Christopher Taber. (1998). “Explaining Rising Wage Inequality: Explorations with a Dynamic General Equilibrium Model of labor Earnings with Heterogeneous Agents." Review of Economic Dynamics 1 (1): 1-58.

Hendel, Igal, Joel Shapiro, and Paul Willen. (2005). "Educational Opportunity and Income Inequality." Journal of Public Economics 89 (5-6): 841-870.

Hornstein, Andreas, Per Krusell, and Giovanni L. Violante. (2005). “The Effects of Technical Change on labor Market Inequalities.” In Handbook of Economic Growth, edited by Philippe Aghion and Steven Durlauf, 1275-1370. Elsevier.

Hoxby, Caroline. (2000). "Testimony Prepared for U.S. Senate, Committee on Governmental Affairs, Hearing on The Rising Cost of College Tuition and the Effectiveness of Government Financial Aid." February 9, 2000, in Senate Committee on Governmental Affairs.

Jeong, Hyeok, Yong Kim, and Iourii Manovskii. (2015). “The Price of Experience." American Economic Review 105 (2): $784-815$.

Jovanovic, Boyan. (1979). "Job Matching and the Theory of Turnover." Journal of Political Economy 87 (5): $972-990$.

Kahn, Lisa. (2013). "Asymmetric Information between Employers." American Economic Journal: Applied Economics 5 (4): $165-205$.

Kambourov, Gueorgui, and Iourii Manovskii. (2013). "A Cautionary Note on using (March) Current Population Survey and Panel Study of Income Dynamics data to study Worker Mobility." Macroeconomic Dynamics 17 (1): 172-194.

Karabarbounis, Loukas, and Brent Neiman. (2014). "The Global Decline of the Labor Share." Quarterly Journal of Economics 129(1): 61-103.

Katz, Lawrence, and Kevin Murphy. (1992). “Changes in Relative Wages, 1963-1987: Supply and Demand Factors." Quarterly Journal of Economics 107 (1): 35-78.

Kaymak, Baris. (2012). "Quantifying the Signaling Role of Education." Mimeo.

Kaymak, Baris, and Markus Poschke. (2016). "The Evolution of Wealth Inequality Over Half a Century: The Role of Taxes, Transfers and Technology." Journal of Monetary Economics 77 (C): 1-25.

Kiley, Michael. (1999). "The Supply of Skilled Labor and Skill-Biased Technological Progress." Economic Journal 109 (458): $708-724$.

Koutmeridis, Theodore. (2013a). "The Market for 'Rough Diamonds': Information, Finance and Wage Inequality in Macroeconomics." PhD diss., University of Warwick.

Koutmeridis, Theodore. (2013b). "The Market for 'Rough Diamonds': Information, Finance and Wage Inequality." SIRE Discussion Paper 2013-32.

Krueger, Dirk, Fabrizio Perri, Luigi Pistaferri, and Giovanni L. Violante. (2010). “Cross-Sectional Facts for Macroeconomists." Review of Economic Dynamics 13 (1): 1-14.

Krugman, Paul. (2000). "And Now for Something Completely Different: An Alternative Model of Trade, Education, and Inequality." In The Impact of International Trade on Wages, edited by Robert Feenstra 15-36. NBER Books.

Lagakos, David, Benjamin Moll, Tommaso Porzio, and Nancy Qian. (2012). “Experience Matters: Human Capital and Development Accounting." NBER Working Paper 18602.

Lange, Fabian. (2007). “The Speed of Employer Learning." Journal of Labor Economics 25 (1): 1-35.

Lee, David. (1999). “Wage Inequality during the 1980s: Rising Dispersion or Falling Minimum Wage?" Quarterly Journal of Economics 114 (3): 977-1023.

Lemieux, Thomas. (2006a). “Postsecondary Education and Increasing Wage Inequality.” American Economic Review 96 (2): $195-199$.

Lemieux, Thomas. (2006b). "Increasing Residual Wage Inequality: Composition Effects, Noisy Data, or Rising Demand for Skill?" American Economic Review 96 (3): 461-498.

Lochner, Lance, and Alexander Monge-Naranjo. (2011). "The Nature of Credit Constraints and Human Capital." American Economic Review 101 (6): 2487-2529.

Lochner, Lance, and Alexander Monge-Naranjo. (2012). "Credit Constraints in Education." Annual Review of Economics 4 (1): $225-256$.

Machin, Stephen, and John Van Reenen. (1998). "Technology and Changes in Skill Structure: Evidence from Seven OECD Countries." Quarterly Journal of Economics 113 (4): 1215-1244.

Machin, Stephen, Alan Manning, and Lupin Rahman. (2003). “Where the Minimum Wage Bites Hard: Introduction of Minimum Wages to a Low Wage Sector." Journal of European Economic Association 1 (1): 154-180.

Mincer, Jacob. (1974). Schooling, Experience, and Earnings. NBER Books.

Murphy, Kevin, and Finis Welch. (1992). "The Structure of Wages.” Quarterly Journal of Economics 107 (1): 285-326.

Primiceri, Giorgio E., and Thijs van Rens. (2009). "Heterogeneous Life-Cycle Profiles, Income Risk and Consumption Inequality." Journal of Monetary Economics 56 (1): 20-39.

Samuelson, Paul. (1958). "An Exact Consumption-Loan Model of Interest with or without the Social Contrivance of Money." Journal of Political Economy 66 (6): 467-482.

Song, Jae, David J. Price, Fatih Guvenen, Nicholas Bloom, and Till von Wachter. (2015). “Firming Up Inequality.” NBER Working Paper 21199.

Spence, Michael. (1973). "Job Market Signaling." Quarterly Journal of Economics 87 (3): 355-374.

Stiglitz, Joseph. (1975). "The Theory of Screening, Education, and the Distribution of Income." American Economic Review 65 (3): 283-300,

Sun, Stephen Teng, and Constantine Yannelis. (2016). "Credit Constraints and Demand for Higher Education: Evidence from Financial Deregulation." Review of Economics and Statistics 98 (1): 12-24.

Teulings, Coen. (2003). “The Contribution of Minimum Wages to Increasing Wage Inequality.” Economic Journal 113 (490): 801-833.

Violante, Giovanni L. (2002). "Technological Acceleration, Skill Transferability, and the Rise in Residual Inequality." Quarterly Journal of Economics 117 (1): 297-398.

Violante, Giovanni L. (2008). "Skill-Biased Technical Change." In The New Palgrave Dictionary of Economics, edited by Steven Durlauf and Lawrence Blume, Second Edition. Palgrave Macmillan.

Weinberg, Bruce. (2004). "Experience and Technology Adoption.” IZA Discussion Paper 1051. 


\section{A1. Online Appendix: Data}

The main data source is the March Current Population Survey, which is constructed in order to represent the US labor market. I use individual data for real weekly earnings from 1963 to 2008. My sample is comprized of white males aged 16 to 64 that work full-time, full-year (FTFY), defined as working 35-plus hours per week, 40-plus weeks per year and who are not self employed. I also exclude those who have a real weekly wage below 67 US dollars (using PCE, base year 1982). We prefer to use weekly earnings, as estimates of hours worked last year from the March CPS appear to be noisy. Moreover, data on usual weekly hours last year are not available prior to the 1976 March CPS. See Koutmeridis (2013a) for an examination of the education, the experience and the gender premium, which apart from white males it also examines wage data for females.

Figure 7 illustrates the domestic credit provided by the banking sector as a percentage of GDP. Domestic credit provided by the banking sector includes all credit to various sectors on a gross basis, with the exception of credit to the central government, which is net. The banking sector includes monetary authorities and deposit money banks, as well as other banking institutions where data are available (including institutions that do not accept transferable deposits but do incur such liabilities as time and savings deposits). Examples of other banking institutions are savings and mortgage loan institutions and buildings and loan associations. Source: International Monetary Fund, International Financial Statistics and data files, and World Bank and OECD GDP estimates. This figure is taken from Hendel et al., (2005).

\section{A2. Online Appendix: Mathematical Proof of Proposition 2 when Firm profits are zero}

In the model firms maximize profits in every period, while workers maximize lifetime earnings. This generates positive profits in the second and third period for the firms. However, knowing that in the second period they will derive profits from the credit constraint high types, firms would be willing to offer a higher wage in the first period to attract those workers. Notice that in this case firms will have losses in the first period and benefits in the second and third, in order to break even in their three-period lifetime. I also allow firms to borrow at zero cost and I prove that even in this case that firms have zero profits the skill premium increases when credit constraints relax.

The new wage for unskilled inexperienced workers in the first period would be higher in this case. The new wage will be the market clearing wage in period 1 plus the transfer from the profits from periods 2 and 3. Formally, $\overline{w_{1}^{u}}=w_{1}^{u}+\tau$. I have solved for $w_{1}^{u}$ in the main paper and here I determine the transfer $\tau$.

The wage for uneducated high types in the second and third period is $w_{2}^{u, h}=\left[q^{h}-\left(1+r^{l}\right) T\right] /(2+$ $\left.r^{l}\right)$ but the productivity for these workers is $q^{h}$. So, the total profit per worker in period 2 and 3 is:

$$
\pi=q^{h}\left(2+r^{l}\right)-q^{h}+T\left(1+r^{l}\right)=\left(q^{h}+T\right)\left(1+r^{l}\right)
$$

The total profit that firms derive from the credit constrained high types in periods 2 and 3, are divided to all the unskilled workers in period 1 . So, the transfer or the benefit that all uneducated inexperienced workers receive in period 1 at the top of $w_{1}^{u}$ is $\tau$ and it is equal to the following:

$$
\tau=\frac{\left(q^{h}+T\right)\left(1+r^{l}\right) P(u \mid h) \pi}{(1-\pi)+P(u \mid h) \pi}
$$

When credit constraints relax, $w_{1}^{u}$ falls. Here I prove that $\tau$ also falls when credit constraints become less severe and that is why the total wage $\overline{w_{1}^{u}}$ also falls. When credit constraints relax $P(u \mid h)$ falls. If the partial derivative of $\tau$ with respect to $P(u \mid h)$ is positive, it means that when $P(u \mid h)$ falls, $\tau$ also falls and this completes the proof.

$$
\begin{gathered}
\frac{\partial \tau}{\partial P(u \mid h)}>0 \\
\left(q^{h}+T\right)\left(1+r^{l}\right) \pi[(1-\pi)+P(u \mid h) \pi]-\left(q^{h}+T\right)\left(1+r^{l}\right) P(u \mid h) \pi>0
\end{gathered}
$$




$$
\left(q^{h}+T\right)\left(1+r^{l}\right) \pi(1-\pi)>0
$$

This is always true. Therefore, even when firms have zero total profits in over the three periods, when credit constraints relax, unskilled inexperienced wages fall $\left(\overline{w_{1}^{u}}=w_{1}^{u}+\tau\right.$ falls as both $w_{1}^{u}$ and $\tau$ fall) and the skill premium for inexperienced workers increases.

\section{A3. Online Appendix: Mathematical Proof of Proposition 3 with a continuum of ability types}

The theoretical model of the thesis assumes that individuals have either high or low ability, $q^{j}$, where $j=\{l, h\}$. I relax this and here I allow ability to take any value from zero to one, $j \in[0,1]$. In particular, I prove that even when ability is a continuous variable the main results still hold.

Let the distribution of ability be uniform and before the relaxation of credit constraints those who have ability $j \in[0, \theta]$ to be uneducated, where $0<\theta<1$. The remaining $j \in[\theta, 1]$ get an education. After the relaxation of credit constraints an additional $\epsilon>0$ gets an education. Before the change, the wage ratio between average educated and average uneducated should be smaller than after the change.

$$
\begin{aligned}
\text { SkillPremium }^{\text {BEFORE }} & <\text { SkillPremium }{ }^{\text {AFTER }} \\
\frac{w_{2}^{\text {s BEFORE }}}{w_{1}^{u}} & <\frac{w_{2}^{\text {s }} \text { AFTER }}{w_{1}^{u}} \\
\frac{\frac{1-\theta}{2}}{\frac{\theta}{2}} & <\frac{\frac{1-(\theta-\epsilon)}{2}}{\frac{\theta-\epsilon}{2}} \\
& \cdots \\
-\epsilon & <0
\end{aligned}
$$

Which is always true. That is why even with a continuum of ability types the main results still hold. I prove this only for the skill premium but the same result holds for the experience premium. 